Review

\title{
Edible halophytes of the Mediterranean basin: Potential candidates for novel food products
}

\author{
S.A. Petropoulos ${ }^{\mathrm{a}, *}$, A. Karkanis ${ }^{\mathrm{a}}$, N. Martins ${ }^{\mathrm{b}}$, I.C.F.R. Ferreira ${ }^{\mathrm{b}, * *}$ \\ a Department of Agriculture Crop Production and Rural Environment, University of Thessaly, Fytokou Street, 38446, Nea Ionia, Magnesia, Greece \\ ${ }^{\mathrm{b}}$ Mountain Research Centre (CIMO), ESA, Polytechnic Institute of Bragança, Campus de Santa Apolónia, 1172, 5301-855 Bragança, Portugal
}

\section{A R T I C L E I N F O}

\section{Keywords:}

Edible greens

Halophytic species

Mediterranean diet

Native plants

Underutilized species

Wild greens

\begin{abstract}
A B S T R A C T
Background: Recent trends in the food science industry and consumers' preferences for diversified diets suggest the consumption of wild greens not only as diet complements but also as healthy and functional foods for targeted conditions, rendering its commercial cultivation of major importance in order to avoid irrational gathering and genetic erosion threats. The Mediterranean basin abounds in wild edible species which have been used for food and medicinal purposes by human throughout the centuries. Many of these species can be found near coastal areas and usually grow under saline conditions, while others can adapt in various harsh conditions including high salinity.

Scope and approach: The aim of this review focuses on listing and describing the most important halophyte species that traditionally have been gathered by rural communities of the Mediterranean basin, while special interest will be given on their chemical composition and health promoting components. Cases of commercially cultivated halophytes will be also presented to highlight their potential as alternative cash crops, while results from in vitro and in vivo health effects will be presented.

Key findings and conclusions: The recent literature has provided useful information regarding the potential of wild halophytes as promising ingredients in functional food products and/or as sources of bioactive compounds. However, further research is needed regarding the chemical characterization of these species under commercial cultivation practices, while further clinical and model trials have to be conducted to assess their long term bioactivity and elucidate potential toxic effects and regulations of safe consumption.
\end{abstract}

\section{Introduction}

Mediterranean basin is thriving with native plants that have been used throughout the centuries by rural communities for food and therapeutic purposes, especially during periods of food scarcity, hence they are also called as "famine food". The diverse climatic conditions and terrain morphology of the wider Mediterranean region have contributed to the existing variation within the various species, with many ecotypes being present throughout the countries around the Mediterranean Sea (Sánchez-Mata et al., 2012). Many of these species are used as leafy greens and are the basic ingredients in many traditional dishes and local recipes of regional interest that constitute the socalled "Mediterranean diet" which is in the epicenter of scientific research during the last decades due to its health promoting effects and contribution to general well-being (Morales et al., 2014). Wild halophytes are usually richer in nutrients and bioactive compounds and have a taste similar to conventional salad crops (Ruiz-Rodríguez et al.,
2011), which are considered as important mediators of its various health effects (Trichopoulou et al., 2000). Apart from hand-picked wild greens, the life style of modern people and the seasonality of these species have created a market niche for commercial cultivation of various species, e.g. Cichorium intybus, C. spinosum, Crithmum maritimum, Capparis spinosa, Portulaca oleracea to name but a few, in order to ensure availability throughout the year and fulfil consumers' demands (Petropoulos et al., 2015, 2016a).

The recent advances in food science and technology dictate the production of novel and healthy food products and incorporation of innovative processing techniques, with wild plants suggesting an important part of the food basket on a global scale, in both developed and developing countries since more than 120 species are being regularly used as dietary components (Bharucha \& Pretty, 2010). Moreover, medicinal properties of various species native in the Mediterranean basin have been confirmed for the treatment and prophylaxis against various chronic diseases that afflict modern societies, including various

\footnotetext{
* Corresponding author. University of Thessaly, School of Agricultural Sciences, Fytokou Street, 38446, N. Ionia, Magnissia, Greece.

** Corresponding author. Polytechnic Institute of Bragança, Campus de Santa Apolónia, 1172, 5301-855 Bragança, Portugal.

E-mail addresses: spetropoulos@uth.gr (S.A. Petropoulos), iferreira@ipb.pt (I.C.F.R. Ferreira).
} 
types of cancer, heart diseases, diabetes and so forth (Ksouri et al., 2012). Therefore, consumers' renewed attention dictate a reversion to former diet habits where special concern is given to balanced nutrition and self-medication through "super" and "healthy foods", dietary supplements, botanical drugs and functional foods (Luczaj et al., 2012).

Considering increasing global climate change and severe conditions that prevail throughout the world, cultivation of conventional crops is facing various limitations related with scarcity of good quality water, temperature increase, salinization and degradation of soil properties and so forth, especially in arid and semi-arid regions of the Mediterranean basin where the abovementioned problems are intensified (Slama, Abdelly, Bouchereau, Flowers, \& Savouré, 2015). Moreover, most of the wild species, are considered as weeds for conventional crops and farmers usually apply chemical fertilizers in order to eradicate them, a practice which in long term could result in extinction of vulnerable species and consequent genetic erosion (Tardío, Pardo-de-Santayana, \& Morales, 2006), as well as in severe changes in terms of biodiversity of agro-ecological systems (Panta et al., 2014). Therefore, it is of utmost importance to propose alternative crop species that can adapt under harsh conditions within the framework of saline agriculture and make for good candidates as potential cash food and medicinal crops (Panta et al., 2014).

In the present review, a list of the most important edible halophytes and salt-tolerant species of the Mediterranean basin will be presented, in order to increase available knowledge regarding the value and uses of halophytes and wild greens. In addition, chemical composition and nutritional value of each species will be presented in order to highlight their pivotal role in human diet on a regular basis, while data from in vitro and in vivo models and ethnopharmacological studies regarding their health effects will be also noted. Finally, the review concludes with future prospects and research pathways that will contribute towards the valorization of native halophytes of the region as ingredients in novel functional food and products as well as sources of bioactive molecules for nutraceutical and medicinal purposes.

\section{Edible halophytes native in the Mediterranean basin}

In the following section the most important edible halophytes of the Mediterranean will be presented in alphabetical order, focusing on wild native species. The selected species have various uses with different plant parts being edible, as shown in Table 1, while they exhibit diverse health effects and chemical composition which are summarized in Tables 2 and 3, respectively, while the most important reported
Table 2

Total phenolics content of various salt tolerant medicinal plants native in the Mediterranean region.

\begin{tabular}{|c|c|c|c|}
\hline Scientific name & Plant parts & $\begin{array}{l}\text { Total Phenolics }{ }^{1} \\
\text { (mg GAE/g } \\
\text { extract) }\end{array}$ & References \\
\hline $\begin{array}{l}\text { Beta vulgaris subsp. } \\
\text { maritima }\end{array}$ & Leaves & 61.91 & Morales et al. (2014) \\
\hline \multirow[t]{4}{*}{ Capparis spinosa $\mathrm{L}$. } & Seeds & $1.31-8.14$ & Tlili et al. (2015) \\
\hline & Leaves & $23.37-427.27$ & Tlili et al. (2017) \\
\hline & $\begin{array}{l}\text { Flower } \\
\text { buds }\end{array}$ & 4.19 & Mansour et al. (2016) \\
\hline & & & Anwar et al. (2016) \\
\hline Cichorium spinosum L. & Leaves & 7.85-39.9* & Petropoulos et al. (2017a) \\
\hline \multirow[t]{3}{*}{ Crithmum maritimum L. } & Leaves & $7.16-35.1$ & Meot-Duros et al. (2008) \\
\hline & Flowers & 32.6 & Mekinić et al. (2016) \\
\hline & Stems & 7.6 & Jallali et al. (2012) \\
\hline \multirow[t]{2}{*}{ Cynara cardunculus } & Leaves & $9.9-10.5$ & Colla et al. (2013) \\
\hline & Heads & $98-132$ & Petropoulos et al. (2017d) \\
\hline \multirow[t]{3}{*}{ Eryngium maritimum L. } & Leaves & $16.44-43.83$ & Meot-Duros et al. (2008) \\
\hline & Seeds & 20 & $\begin{array}{l}\text { Amessis-Ouchemoukh } \\
\text { et al. (2014) }\end{array}$ \\
\hline & & & Mejri et al. (2017) \\
\hline Inula crithmoides $\mathrm{L}$. & $\begin{array}{l}\text { Aerial } \\
\text { parts }\end{array}$ & $6.7-14.1$ & Jallali et al. (2014) \\
\hline \multirow[t]{2}{*}{ Lepidium latifolium L. } & Aerial & $0.0 .-172.4$ & Xiang et al. (2017) \\
\hline & parts & $26.89-50.51$ & $\begin{array}{l}\text { Kaur, Bhat, et al. (2013) } \\
\text { and Kaur, Hussain, et al. } \\
\text { (2013) }\end{array}$ \\
\hline \multirow[t]{3}{*}{ Plantago coronopus L. } & Roots & $0.56-30.6$ & Pereira et al. (2017b) \\
\hline & Leaves & $2.07-28.1$ & Jdey et al. (2017) \\
\hline & Flowers & $1.26-15.7$ & \\
\hline Portulaca oleracea L. & $\begin{array}{l}\text { Leaves and } \\
\text { stems }\end{array}$ & $7.65-20.1$ & $\begin{array}{l}\text { Petropoulos et al. (2015) } \\
\text { Ramadan et al. (2017) }\end{array}$ \\
\hline Salicornia herbaceae L. & $\begin{array}{l}\text { Whole } \\
\text { plants }\end{array}$ & 53.8 & Essaidi et al. (2013) \\
\hline Suaeda fruticosa $\mathrm{L}$. & Shoots & 31.7 & $\begin{array}{l}\text { Oueslati, Trabelsi, et al. } \\
\text { (2012); Oueslati, Ksouri, } \\
\text { et al. (2012) }\end{array}$ \\
\hline
\end{tabular}

$\overline{{ }^{1} \text { Total phenolic content is expressed as gallic acid (GAE) equivalents (mg gallic acid } g^{-1}}$ dry weight (DW)).

*Total phenolic compounds as determined by LC-DAD-ESI/MS.

compounds are presented in Fig. 1. The various adaptation mechanisms to saline conditions that these species have developed through selection are presented in Fig. 2.

Table 1

The most important edible halophytes of the Mediterranean basin.

\begin{tabular}{|c|c|c|c|c|}
\hline Scientific name & Common name & Family & Plant part used & References \\
\hline Suaeda fruticosa Forssk. & Shrubby seablight & \multirow{3}{*}{ Amaranthaceae } & Seeds & Weber et al. (2007) \\
\hline Salicornia herbacea L. & Grasswort & & Seeds & Kang et al. (2014) \\
\hline Beta vulgaris subsp. maritima (L.) Arcang. & Wild beet & & Aerial parts & Zardi-Bergaoui et al. (2017) \\
\hline Crithmum maritimum L. & Sea fennel & \multirow[t]{2}{*}{ Apiaceae } & Leaves, stems and flowers & Pereira et al. (2017a) \\
\hline Eryngium maritimum L. & Sea holly & & Leaves & Mejri et al. (2017) \\
\hline Inula crithmoides $\mathrm{L}$ & Golden samphire & \multirow[t]{3}{*}{ Asteraceae } & Aerial parts & Fontana et al. (2014) \\
\hline Cichorium spinosum L. & Spiny chicory & & Leaves & Petropoulos et al. (2017a) \\
\hline Cynara cardunculus var. altilis & Gardoon & & Leaves & Lattanzio et al. (2009) \\
\hline Lepidium latifolium $\mathrm{L}$. & Pepperwort & Brassicaceae & Leaves & Conde-Rioll et al. (2017) \\
\hline Capparis spinosa L. & Caper & Capparaceae & Leaves and seeds & Chedraoui and Rajjou (2017) \\
\hline Salsola soda L. & Opposite-leaved saltwort & Chenopodiaceae & Aerial parts & Polat and Satıl (2012) \\
\hline Chenopodium album $\mathrm{L}$. & Lambsquarters & & Leaves & Salam Jekendra et al. (2011) \\
\hline Plantago coronopus L. & Buck's-horn plantain & Plantaginaceae & Leaves and flowered part & Jdey et al. (2017) \\
\hline Portulaca oleracea L. & Common purslane & Portulacaceae & Leaves and stems & Petropoulos et al. (2015; 2016b) \\
\hline Tribulus terrestris & Puncturevine & Zygophyllaceeae & Stems, leaves and fruits & Šalamon et al. (2016) \\
\hline
\end{tabular}


Table 3

Biological activity of the selected medicinal halophytes and their constituents.

\begin{tabular}{|c|c|c|}
\hline Scientific name & Biological activity & Reference \\
\hline $\begin{array}{l}\text { Beta vulgaris subsp. maritima } \\
\text { (L.) Arcang. }\end{array}$ & Antioxidant, Antiholinesterase, Anti-tyrosinase, Cytotoxic & Zardi-Bergaoui et al. (2017) \\
\hline Capparis spinosa $\mathrm{L}$. & $\begin{array}{l}\text { Antioxidant, Antidiabetic, Anti-hyperlipemic, Anti-helminthic, Anti- } \\
\text { inflammatory, Cytotoxic, Neuroprotective }\end{array}$ & $\begin{array}{l}\text { Akkari et al. (2016); Azhary et al. (2017); Bakr \& Bishbishy (2016); } \\
\text { Mollica et al. (2017); Tlili et al. (2017); Turgut et al. (2015); Anwar et al. } \\
\text { (2016) }\end{array}$ \\
\hline Cichorium spinosum $\mathrm{L}$. & Antioxidant, Detoxifying & Brieudes et al. (2016) \\
\hline Chenopodium album L. & $\begin{array}{l}\text { Antioxidant, Antimicrobial, Antirrheumatic, Anticonceptive, Ant- } \\
\text { inflammatory, Laxative }\end{array}$ & $\begin{array}{l}\text { Beyrouthy et al. (2008); Ksouri et al. (2011); Salam Jekendra et al. } \\
\text { (2011) }\end{array}$ \\
\hline Crithmum maritimum L. & $\begin{array}{l}\text { Antioxidant, Anti-cholinesterase, Vasoactive, Antibacterial, Cytotoxic, } \\
\text { Diuretic, Antiscorbutic, Depurative, Digestive, Anti-inflammatory, } \\
\text { Antiplatelet-aggregator }\end{array}$ & $\begin{array}{l}\text { Jallali et al. (2012); Kulisic-Bilusic et al. (2010); Mekinić et al. (2016); } \\
\text { Meot-Duros and Magné (2009); Meot-Duros et al. (2010); Pereira et al. } \\
\text { (2017a) }\end{array}$ \\
\hline Cynara cardunculus L. & Anticarcinogenic, Antioxidative, Antibacterial, Hepatoprotective & Kollia et al. (2016); Lattanzio et el. (2009) \\
\hline Eryngium maritimum $\mathrm{L}$. & Antioxidant, Cytotoxic, Anti-inflammatory, Antinociceptive & $\begin{array}{l}\text { Amessis-Ouchemoukh et al. (2014); Küpeli et al. (2006); Mejri et al. } \\
\text { (2017); Meot-Duros et al. (2008); Yurdakök and Baydan (2013) }\end{array}$ \\
\hline Inula crithmoides $\mathrm{L}$ & $\begin{array}{l}\text { Antioxidant, Anti-tyrosinase, Antifungal, Antibacterial, Anticlastogenic, } \\
\text { Antimutagenic, Herbicidal }\end{array}$ & $\begin{array}{l}\text { Abdel-Wahhab et al. (2008); Andreani et al. (2013); Bucchini et al. } \\
\text { (2015); Jallali et a. (2014); Jdey et al. (2017); Lopes et al. (2016); } \\
\text { Malash et al. (2015); Omezzine et al. (2011) }\end{array}$ \\
\hline Lepidium latifolium $\mathrm{L}$. & Antioxidant, Anitumor, Anticancer & $\begin{array}{l}\text { Conde-Rioll et al. (2017); Hanschen et al. (2015); Tabassum and Ahmad } \\
\text { (2011); Xiang et al. (2017) }\end{array}$ \\
\hline Plantago coronopus L. & $\begin{array}{l}\text { Antioxidant, Anti-cholinesterase, Anticancer, Antimicrobial, Anti- } \\
\text { inflammatory, Analgesic, Astringent, Expectorant, Diuretic, } \\
\text { Antipyretic, Emollient }\end{array}$ & $\begin{array}{l}\text { González-Tejero et al. (2008); Jdey et al. (2017); Neves et al. (2009); } \\
\text { Pereira et al. (2017b) }\end{array}$ \\
\hline Portulaca oleracea L. & $\begin{array}{l}\text { Antioxidant, Anti-mutagenic, Cardioprotective, Anti-inflammatory, } \\
\text { Anti-nociceptive, Anti-hyperlipemic, Anti-atherogenic, } \\
\text { Hepatoprotective, Immunomodulatory }\end{array}$ & $\begin{array}{l}\text { Alam et al. (2014); Choi et al. (2016); Chowdhary et al., 2013); Ramadan } \\
\text { et al. (2017); YouGuo et al. (2009) }\end{array}$ \\
\hline Salicornia herbacea L. & $\begin{array}{l}\text { Antiproliferative, Anticancer, Cytotoxic, Anti-oxidation, Anti- } \\
\text { thrombosis, Anti-HMGB1 }\end{array}$ & $\begin{array}{l}\text { Choi et al. (2016); Kang et al. (2014); Ksouri et al. (2011); Lee et al. } \\
\text { (2016); Tuan et al. (2015); Zhao et al. (2014) }\end{array}$ \\
\hline Salsola soda L. & Antioxidant, Anti-cholinesterase, $\alpha$-amylase inhibitor & Loizzo et al. (2007); Polat and Satıl (2012); Tundis et al. (2007; 2009) \\
\hline Suaeda fruticosa Forssk. & Antioxidant, Hypoglycemic, Anti-hyperlipemic & $\begin{array}{l}\text { Benwahhoud et al. (2001); Ksouri et al. (2011); Oueslati, Trabelsi, et al. } \\
\text { (2012); Oueslati, Ksouri, et al. (2012); Qasim et al. (2017) }\end{array}$ \\
\hline Tribulus terrestris $\mathrm{L}$. & Antioxidant, Aphrodisiac, Anticancer & $\begin{array}{l}\text { Hammoda et al. (2013); Šalamon et al. (2016); Vale et al. (2017); Wei } \\
\text { et al. (2014) }\end{array}$ \\
\hline
\end{tabular}

\section{Beta vulgaris subsp. maritima (L.) Arcang}

Sea or wild beet (Beta vulgaris subsp. maritima (L.) Arcang.) belongs to the Chenopodiaceae family and is a wild relative of cultivated beets (B. vulgaris) which thrives in salt marshes and seashore cliffs and exhibits high salt-stress tolerance (Ribeiro et al., 2016) (Fig. 3a). In a recent study, Ribeiro et al. (2016) observed that sea beet populations from contrasting environments showed physiological plasticity and recovered from severe stress conditions (drought and salinity stress), while Skorupa et al. (2016) reported that several genes related with carbon fixation, biosynthesis of ribosomes and expansion and formation of cell walls are involved in salt tolerance. The edible parts of the plant are its leaves and leaf stems which are eaten as cooked or raw greens throughout the Mediterranean basin (Turner et al., 2011).

\subsection{Chemical composition}

According to Morales et al. (2014), the basal leaves of the plant are good sources of vitamin E vitamers ( $\alpha$ - and $\gamma$-tocopherol), vitamin C and citric and oxalic acid. In the same study, the authors detected a significant amount of total phenolics and flavonoids (61.91 and $21.55 \mathrm{mg} \mathrm{GAE} / \mathrm{g}$ extract, respectively), which contribute to antioxidant properties of the species (Morales et al., 2014). Moreover, the basal leaves of the plant are good sources of $\alpha$-linolenic (57.8\%), linoleic (21.28\%) and palmitic acid (11.03\%) (Zardi-Bergaoui et al., 2017). The essential oils of the aerial parts of the plant consist of oxygenated sesquiterpenes, sesquiterpene hydrocarbons and apocarotenoids, while the main detected compounds were $\gamma$-irone, $\alpha$-cadinol, T-cadinol, bicyclogermacrene and $\delta$-cadinene (Zardi-Bergaoui et al., 2017).

\subsection{Health effects}

Regarding the medicinal properties, Zardi-Bergaoui et al. (2017) found that essential oil from aerial parts of wild beet displays strong antioxidant activity, as well as cytotoxic effect against A549 cell lines. Moreover, ethnopharmacological studies have recorded the use of cooked leaves and leaf stems against digestive disorders (GonzálezTejero et al., 2008), burns, throat pains and anemia (Guarrera \& Savo, 2013), while the juice of squeezed leaves and cooked leaves exhibit emollient, digestive, diuretic and laxative properties (Morales et al., 2014). However, the high content of oxalic acid in edible parts (581 $\mathrm{mg} / 100$ f.w.) indicates that people susceptible to kidney stone formation should avoid regular consumption of B. maritima leaves (Morales et al., 2014).

\section{Capparis spinosa $\mathrm{L}$}

Caper (Capparis spinosa L.) is a perennial xerophytic plant and a member of the Capparaceae family, which is native in the Mediterranean basin (Chedraoui \& Rajjou, 2017) (Fig. 3b). The edible part of the plants include its leaves, flower buds and fruit, while apart from culinary purposes plant tissues are a basic ingredient in traditional medicine (Chedraoui \& Rajjou, 2017). According to Mahmood, Aslam, Rehman, and Naqvi (2013), within C. spinosa species there are two subspecies common in the Mediterranean basin C. spinosa subsp. spinosa and $C$. spinosa subsp. rupestris. The species is both drought and salt tolerant due to its extended root system and thrives under the Mediterranean arid and semi-arid conditions (Mahmood et al., 2013).

\subsection{Chemical composition}

Caper contains several classes of bioactive molecules, among them alkaloids (capparisine, tetrahydroquinolin, stachydrin, cappariloside A, flazin, capparine, spermidine alkaloids), saponins, terpenes (citral, eukalyptol, $\beta$-pinene, myrcene, eugenol, and terpineol), phenolic compounds (caffeic acid, catechin, epicatechin, chlorogenic acid, coumarin, 
a.<smiles>O=C(O)c1cc(O)c(O)c(O)c1</smiles>

b.<smiles>O=c1c(O)c(-c2ccc(O)c(O)c2)oc2cc(O)cc(O)c12</smiles>

c.<smiles>O=C(/C=C/c1ccc(O)c(O)c1)O[C@H](C(=O)O)[C@@H](OC(=O)/C=C/c1ccc(O)c(O)c1)C(=O)O</smiles><smiles>O=C(/C=C/c1ccc(O)c(O)c1)O[C@@H]1C[C@@](O)(C(=O)O)C[C@H](O)[C@H]1O</smiles>

e.<smiles>C=C[C@H](O)C#CC#C[C@H](O)/C=C\CCCCCCC</smiles>

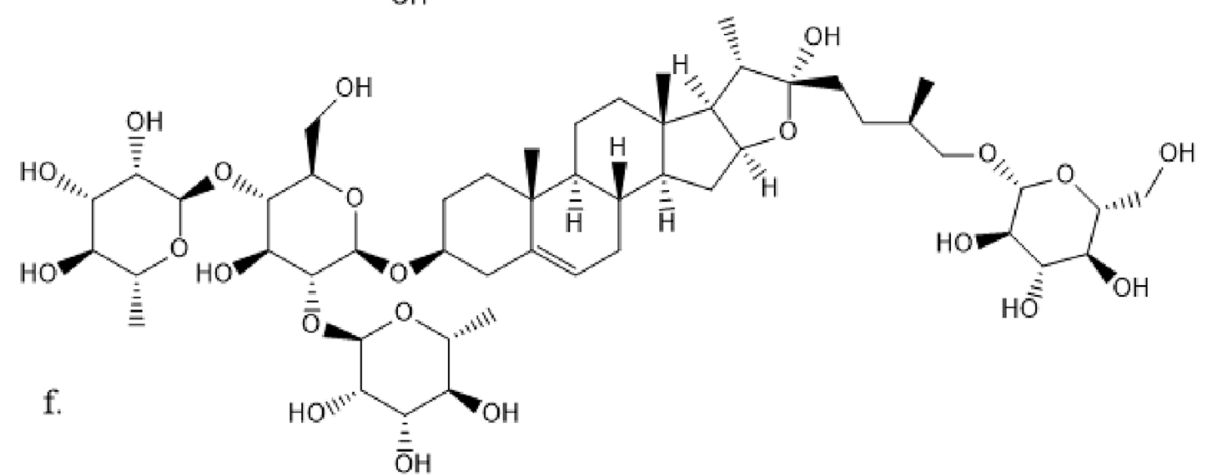<smiles>O=C(/C=C/c1ccc(-c2cc(=O)c3c(O)cc(O)cc3o2)cc1O)O[C@H]1[C@@H](O)[C@H](O)[C@](OC(=O)/C=C/c2ccc(O)c(O)c2)(C(=O)O)C[C@H]1OC(=O)/C=C/c1ccc(O)c(O)c1</smiles>

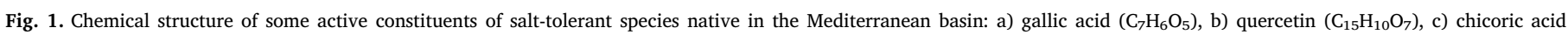
$\left(\mathrm{C}_{22} \mathrm{H}_{18} \mathrm{O}_{12}\right)$, d) chlorogenic acid $\left(\mathrm{C}_{16} \mathrm{H}_{18} \mathrm{O}_{9}\right)$, e) falcarindiol $\left(\mathrm{C}_{17} \mathrm{H}_{24} \mathrm{O}_{2}\right)$, f) protodioscin $\left(\mathrm{C}_{51} \mathrm{H}_{84} \mathrm{O}_{22}\right)$, g) luteolin $\left(\mathrm{C}_{15} \mathrm{H}_{10} \mathrm{O}_{6}\right)$, and h) cynarin $\left(\mathrm{C}_{25} \mathrm{H}_{24} \mathrm{O}_{12}\right)$.

ferulic acid, gallic acid, kaempferol, luteolin, naringenin-7-O-glucoside, naringin, $p$-coumaric acid, protocatechuic acid, quercetin, resveratrol, rutin, syringic acid, taxifolin and vanillic acid), glucosinolates (glucocapperin, butyl-isothiocyanate, isopropyl-isothiocyanate, glucobrassicin and glucoiberin), lipids and liposoluble compounds (tocopherols: $\alpha$ - and $\gamma$-tocopherol, carotenoids: $\beta$-carotene and lutein, and fatty acids) and ascorbic acid (Aichi-Yousfi et al., 2016). Other important secondary metabolites include resins, tannins, anthocyanins, organic acids, aldehydes and ketones, monoterpenes and sesquiterpenes, polysaccharides and sugars, as also hemicelluloses and pectin which have also been reported for caper plant tissues (Akkari et al., 2016; Mansour et al., 2016). Seed oil is rich in unsaturated fatty acids, while apart from commonly found oleic, linoleic and palmitic acid it also contains significant amounts of vaccenic acid (Argentieri, Macchia, Papadia, Paolo, \& Avato, 2012). Also important to point out is that chemical composition of caper is affected by various factors such as environmental conditions, genotype, harvesting stage and time, plant part, as also by extraction solvent used (Aichi-Yousfi et al., 2016; Chedraoui \& Rajjou, 2017; Tlili, Feriani, Saadoui, Nasri, \& Khaldi, 2017).

\subsection{Health effects}

Capparis spinosa exert a pronounced antioxidant activity, being 


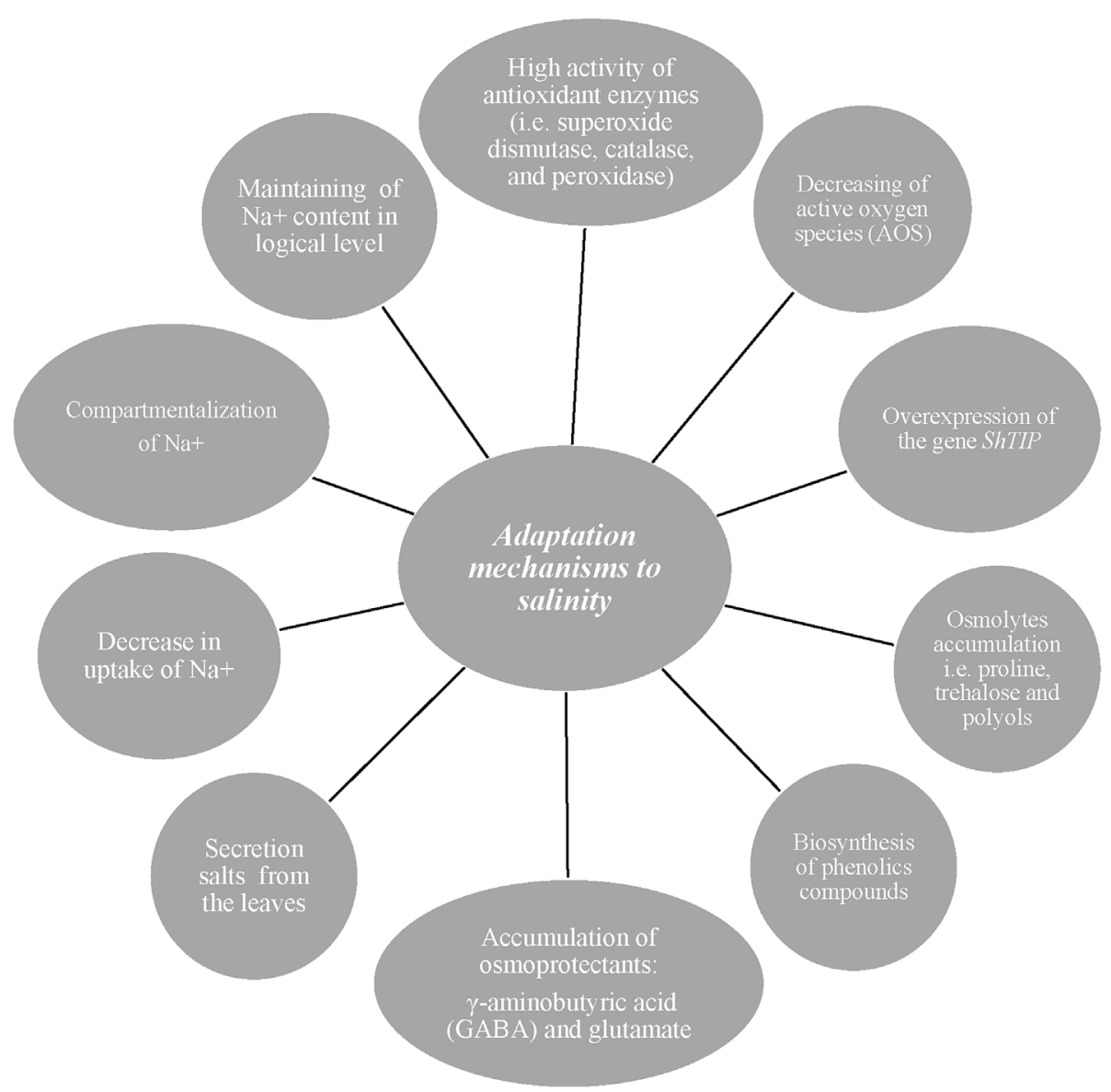

Fig. 2. Selected adaptation mechanisms of native Mediterranean plant species to salinity.

clearly evident its effect as lipid peroxidation inhibitor, free radical's scavenger and modulator of antioxidant enzymes (i.e. superoxide dismutase and catalase) (Mansour et al., 2016). The in vivo antidiabetic and anti-hyperlipidemic properties of this halophytic plant has also been reported (Mollica et al., 2017), while animal studies have confirmed nephroprotective and hepatoprotective effects of leaf extracts (Tlili et al., 2017). Mollica et al. (2017) reported a significant decrease in fasting blood glucose levels and glycosylated hemoglobin in treated patients when compared to control group; triglyceride levels also decreased in a significant manner, without causing kidney toxicity or other side effects. Cytotoxic activity of the plant was also assessed, being observed a high selectivity against human cancer cell lines, namely: breast adenocarcinoma (MCF-7), hepatocellular carcinoma (Hep-G2), and colon carcinoma (HCT-116 and HT-29) cells, suggesting their upcoming use as a promissory candidate for nutraceutical researches (Bakr \& Bishbishy, 2016). Anthelmintic effects of the species were also reported as being related to its phenolic content and antioxidant activity (Akkari et al., 2016). The authors found a promissory anthelmintic activity against eggs and adult worms of Haemonchus contortus from sheep, while they correlated these effects to the high content of phenolic compounds (i.e. flavonoids and tannins (Akkari et al., 2016). The anti-inflammatory activity of caper was also detected in animal studies, where leaf extracts were able to reduce edema in treated mice in a dose-dependent manner, as also a significant decrease in immune cells infiltration, vasodilatation and in dermis thickness (Azhary et al., 2017). Furthermore, leaf extracts of the same study inhibited the cytokine gene expression, namely IFN $\gamma$, IL-17 and IL-4 (Turgut et al., 2015). More interestingly, this plant also conferred a significant protection against DNA bands damage and on cognitive impairment induced by D-galactose in mice via inhibition of oxidative stress (Anwar, Muhammad, Hussain, Zengin, \& Alkharfy, 2016), leading to an increase of memory retention and attenuating D-galactose-induced learning dysfunctions in mice. Finally, and not least important to point out is that this plant is traditionally used to prevent and/or treat a number of health disorders such as diabetes, hepatitis, obesity and kidney problems, and cardiovascular, digestive, respiratory system and nutritional disorders (Anwar et al., 2016).

\section{Chenopodium album $\mathrm{L}$}

Lambsquarters or white goosefoot (Chenopodium album L., Chenopodiaceae) is an important annual broad-leaved and moderately tolerant to $\mathrm{Cl}^{-}$and $\mathrm{SO}_{4}{ }^{2-}$ induced salinity weed, while it is also considered a wild edible green with young shoots and leaves being used as salad or cooked vegetables (Bianco, Santamaria, \& Elia, 1998; Panta et al., 2014) (Fig. 3c). In the study of Ivanova et al. (2016), it was reported that $C$. album has the ability to maintain the concentration of $\mathrm{Na}^{+}$and $\mathrm{Cl}^{-}$in cell organs at a level similar to untreated plants by using them for osmoregulatory purposes, while concomitant ultrastructural changes in cell organelles were observed. According to these researchers, the contribution of $\mathrm{Na}^{+}$and $\mathrm{Cl}^{-}$to osmolarity in leaves increased with increasing $\mathrm{NaCl}$ concentrations in nutrient solution up to the highest concentration (more than $100 \mathrm{mmol} / \mathrm{kg}$ f.w.) at $250 \mathrm{mM}$ $\mathrm{NaCl}$, without a further increase being observed at higher salt concentrations, which indicates an efficient mechanism of using these ions for osmoregulation along with $\mathrm{K}^{+}$which is the usual plant osmoregulator.

\subsection{Chemical composition}

C. album is a good source of $\beta$-carotene, diterpenes and retinol precursors, since it exhibited a significant in vivo efficacy in rising 

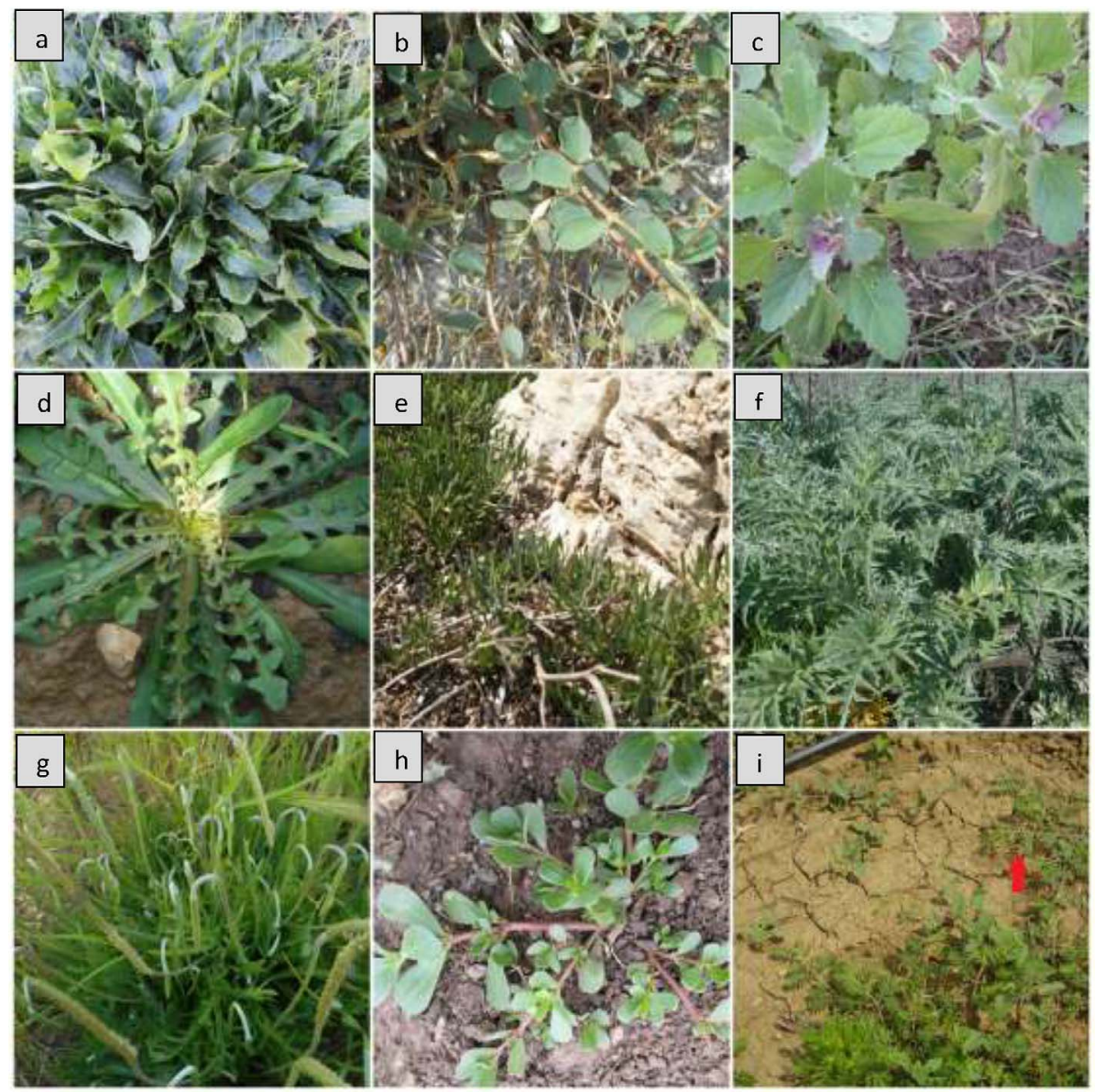

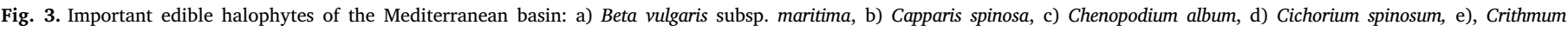
maritimum. f) Cynara cardunculus, g) Plantago coronopus, h) Portulaca oleracea, and i) Tribulus terrestris.

plasma retinol levels in retinol deficient rats (Sangeetha \& Baskaran, 2010). Moreover, Guil, Rodríguez-García, and Torija (1997) detected

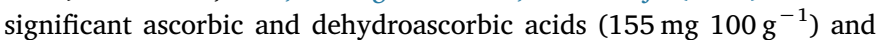
carotenoids $\left(12.5 \mathrm{mg} 100 \mathrm{~g}^{-1}\right.$ ) content, while it contains significant amounts of minerals such as $\mathrm{K}, \mathrm{Mg}$ and $\mathrm{Ca}$, especially when comparing to common cultivated vegetables Bianco et al. (1998). However, the high oxalic acid content $\left(1100 \mathrm{mg} 100 \mathrm{~g}^{-1}\right)$ observed in the study of Guil et al. (1997) indicates potential toxic effects when high amounts ( $>400 \mathrm{~g}$ on a daily basis) are consumed, especially from people that are sensitive to kidney stone formation.

\subsection{Health effects}

With respect to medicinal properties, Salam Jekendra, Joylani, Rebika, \& Priyadarshini (2011) observed that C. album extracts exhibited higher antioxidant activity $\left(\mathrm{IC}_{50}=206 \mu \mathrm{g} / \mathrm{ml}\right.$ ) than vitamin $\mathrm{C}$ $\left(\mathrm{IC}_{50}=15.1 \mu \mathrm{g} / \mathrm{ml}\right)$ and quercetin $\left(\mathrm{IC}_{50}=6.45 \mu \mathrm{g} / \mathrm{ml}\right)$. Besides, Lone et al. (2017) observed that the extracts of C. album exhibited considerable antimicrobial activity against Staphylococcus aureus, Pseudomonas multocida and Escherichia coli. Moreover, Beyrouthy, Nelly, Annick, and Frederic (2008) have described the use of alcoholic decoctions of aerial parts against rheumatism and arthritis in traditional medicine of Lebanon, while Ksouri et al. (2012) have reported unspecified medicinal uses of the species, mostly in the region of Albania. Other therapeutic properties include diuretic, laxative, sedative, hepatoprotective and antiparasitic activities, and notable anti-pyretic, antinoceptive, anti-inflammatory and cancer preventing effects (Ksouri et al., 2012).

\section{Cichorium spinosum $\mathrm{L}$}

Spiny chicory (Cichorium spinosum L., Asteraceae) is a perennial species commonly found in coastal and mountainous areas throughout the Mediterranean region, while it has been recently cultivated commercially as a leafy vegetable (Petropoulos et al., 2016a, 2017b) (Fig. 3d). It is a common ingredient of the so-called Mediterranean diet whose beneficial health effects have been confirmed in numerous studies (Ntatsi, Aliferis, Rouphael, \& Napolitano, 2017). It is also considered as a highly salt-tolerant species, with the main osmoprotectants compounds being $\gamma$-aminobutyric acid (GABA), glutamate, pyroglutamate, L-proline, and sucrose, as well as total phenolics content which serve as antioxidant compounds (Klados \& Tzortzakis, 2014).

\subsection{Chemical composition and health effects}

This species exhibits considerable antioxidant activity since its leaves contains tocopherols and phenolic compounds (Petropoulos, Fernandes, Barros, \& Ferreira, 2017). Alpha-Tocopherol, gamma-Tocopherol, 5-O-Caffeoylquinic acid, chicoric acid, caftaric acid kaempferol-3-O-glucuronide, quercetin-3-O-glucuronide, and apigenin-O-glucuronide are the main bioactive compounds isolated from the leaves of the species (Brieudes et al., 2016). Moreover, Michalska and Kisiel (2007) and Melliou, Magiatis, and Skaltsounis (2003) detected four alkylresorcinol derivative (cichoriol A, B, C and D), various sesquiterpene lactones ((4R)-3,4-dihydrolactucopicrin, lactucin and its derivatives, leucodin, tanacetin) and four coumarins (umbelliferone, scopoletin, aesculetin and cichoriin 4). Regarding the health effects of the species, there is limited number of reports which focus mainly on the 
antioxidant compounds content. According to a recent study, water decoctions of $C$. spinosum leaves exhibit significant antioxidant activities and liver detoxifying properties which could be attributed to its high contents in chicoric and caftaric acid (Brieudes et al., 2016).

\section{Crithmum maritimum L}

Sea fennel (Crithmum maritimum L.) is a facultative and perennial halophyte, very common in several Mediterranean countries such as Greece, Tunisia and Spain (Jallali et al., 2012; Pereira et al., 2017a; Renna \& Gonnella, 2012). It is an edible and medicinal species which is commonly used in traditional dishes throughout the Mediterranean basin, while it usually grows within coastal areas, piers, rocks and sandy beaches (Renna \& Gonnella, 2012) (Fig. 3e). The edible parts of the species are its leaves, which can be consumed fresh as salad vegetables, or pickled, while Renna, Gonnella, Caretto, Mita, and Serio (2017) have suggested the use of dried leaves for human consumption, as well as a coloring agent. Moreover, Siracusa et al. (2011) suggested the use of flower tops and stalks infusions as herbal teas, while Pereira et al. (2017b) reported that all aerial parts can be an alternative source for health promoting beverages. According to Ben Amor, Ben Hamed, Debez, Grignon, \& Abdelly (2005), the salt tolerance of the species may be is due to its ability to exhibit high activities of antioxidant enzymes, like superoxide dismutase (SOD), catalase (CAT), and peroxidase (POD), preventing the accumulation of active oxygen species (AOS).

\subsection{Chemical composition}

Sea fennel contains a wide variety of chemical constituents. Phenolic compounds represent a small but interesting proportion in both stems, leaves and flowers of $C$. maritimum, being the phenolic acids, chlorogenic acid, followed by neochlorogenic, cryptochlorogenic, ferulic and caffeoylquinic acids and its derivatives the most commonly detected phenolic compounds (Jallali et al., 2012). Interesting amounts of gallic, caffeic, vanillic, rosmarinic and p-coumaric acids were also identified and quantified in this edible halophyte (Jallali et al., 2012), while small amounts of trans-2-hydroxycinnamic and trans-cinnamic acids were also reported. Moreover, the flavonoids rutin, apigenin, quercetin-3-galactoside, epicatechin, epigallocatechin, catechin, and even other polyphenols, such as pyrocatechol and 4-hydroxybenzaidehyde are also present, but in low amounts (Jallali et al., 2012; Meot-Duros et al., 2010). Volatile compounds, such as limonene, $\alpha$-pinene, $p$-cimene, $\gamma$-terpinene, $\beta$-myrcene, thymol, carvacrol, eugenol, $\beta$-ionone, dillapiole, anisaldehyde, $\beta$-caryophyllene, carvone, myristicine, have been also identified in essential oils of various plant parts (Atia, Debez, Barhoumi, \& Abdelly, 2010; Burczyk, Wierzchowska-Renke, Glowniak, Glowniak, \& Marek, 2002). Small amounts of coumarins, namely two furanocumarins, scopoletin and scoparone were also identified (Atia et al., 2010; Burczyk et al., 2002). More recently, a polyacetylene compound, namely falcarindiol was also identified in C. maritimum leaf extracts (Meot-Duros et al., 2010), from which very interesting bioactive effects have been proposed. Seeds contain significant amounts of oils ( $44.4 \%$ on d.w. basis) which are similar in composition to olive and canola oil being consisted mainly of oleic (78.6\%), linoleic (15.4\%) and palmitic acid (4.8\%) (Atia et al., 2010).

\subsection{Health effects}

Chrithmum maritimum is a medicinal halophyte with a widely recognized antioxidant capacity, being particularly evident their antiradical, reducing power and lipid peroxidation inhibition abilities (Kulisic-Bilusic, Blažević, Dejanović, Miloš, \& Pifat, 2010; Meot-Duros \& Magné, 2009). However, its biological potential is highly affected by the content in bioactive molecules, which are directly influenced by physiological stage and extraction method selected (Jallali et al., 2012).
Furthermore, no significant toxicity was detected against four different mammalian cell lines, which indicates that $C$. maritimum may be a safe and rich source of biomolecules to be used for multiple pharmaceutical purposes (Pereira et al., 2017a). Another aspect regarding the health effects of the species is that the antioxidant activity of plant extracts is markedly higher than essential oils (Mekinić et al., 2016). On the other hand, a pronounced ability to inhibit acetylcholinesterase and butyrylcholinesterase activity was also observed when both the plant extracts and essential oils were used, although the potency of essential oils was higher than the extracts (Mekinić et al., 2016). In the same study, the authors found strong vasoactive effects in the noradrenaline-precontracted rat aortic rings, namely all the examined samples evidenced a high vasodilatory potency (Mekinić et al., 2016). An appreciable antimicrobial activity was also observed for this halophyte, being able to strongly inhibit the growth of Gram-positive (S. aureus, S. faecalis, Bacillus cereus, B. subtilis and Micrococcus luteus) and Gram-negative (E. coli, Salmonella typhi and $P$. aeruginosa) bacteria in a similar extent to the widely used antibiotic gentamicine (Meot-Duros et al., 2010). Besides, and also interesting to highlight is that $C$. maritimum also evidenced a pronounced cytotoxic activity against L1210 (mouse lymphocytic leukemia), CEM-C7H2 (lymphocytic leukemia) and even RPMI-8226 (human myeloma) cell lines, without displaying cytotoxic potential against FHs 74 Int. (normal human intestinal cells) cell line (Meot-Duros et al., 2010). Moreover, sea fennel has been widely used in traditional medicine as a diuretic, antiscorbutic, depurative, digestive and purgative, as also anti-inflammatory, antiplatelet-aggregator and antimutagenic, which shows the high potential for possible uses of the species as a source of bioactive molecules for medicinal purposes (MeotDuros et al., 2010). Pereira et al. (2017a) have also observed that sea fennel exhibits strong antioxidant activity, which is closely associated to its high content of phenolic compounds such as chlorogenic acid. In addition, Meot-Duros et al. (2010) isolated falcarindiol from leaves extracts, which exhibited cytotoxicity against IEC-6 cells.

\section{Cynara cardunculus $\mathrm{L}$}

Cardoon (Cynara cardunculus L., Asteraceae) is a species native in the Mediterranean basin, which gradually has adapted in various microclimates and abiotic stress factors, including saline soils and water deficit (Ceccarelli et al., 2010). Three botanical varieties are included in the species, namely wild cardoon (C. cardunculus var. sylvestris (Lamk) Fiori), and globe artichoke (C. cardunculus var. scolymus (L.) Fiori) and cultivated cardoon (C. cardunculus var. altilis DC; Pagnotta, Fernandez, Sonnante, and Egea-Gilabert (2017)), which derived from wild cardoon (Ceccarelli et al., 2010). The edible parts of wild and cultivated plants are the immature inflorescences or heads which are used in many traditional dishes throughout the Mediterranean countries, while the whole plant may be used for medicinal and industrial purposes, as well as in the food industry as natural rennet for cheese production (Fernández, Curt, \& Aguado, 2006) (Fig. 3f). According to Colla et al. (2013) wild cardoon and globe artichoke are more salt sensitive comparing to cultivated cardoon, probably due to less efficient osmoregulatory mechanisms, as being evidenced by lower $\mathrm{Na}$ accumulation and higher proline content in cultivated cardoon leaves (Lattanzio, Kroon, Linsalata, \& Cardinali, 2009).

\subsection{Chemical composition}

Cardoon plant parts contain several bioactive compounds, with chlorogenic acid and lutein derivatives being the most pronounced ones (Lattanzio et al., 2009). The majority of phenolic compounds consists of caffeic acid derivatives, with caffeoylquinic acid derivatives such as chlorogenic acid and cynarin being those credited with significant therapeutic activities (Lattanzio et al., 2009). Other phenolic compounds have also been detected in plant parts, including cumaric acid, luteolin derivatives and apigenin (Petropoulos, Pereira, Ntatsi, 
Danalatos, Barros, \& Ferreira, 2017; Petropoulos, Pereira, Barros, \& Ferreira, 2017). Moreover, according to Petropoulos et al. (2017d) fatty acids of artichoke heads consist mainly of palmitic and linolenic acid (42.9 and 29.6, respectively). Flower heads are one of the richest vegetable sources of inulin with the highest polymerization degree among the various plant species, while they are also considered rich sources of minerals and dietary fibers (Ceccarelli et al., 2010). In a recent study, Colla et al. (2013) observed that increased salinity in the nutrient solution improved the quality features of leaves by increasing their antioxidant activity, total polyphenols, chlorogenic acid, cynarin and luteolin levels, while apigenin was affected in a genotype dependent manner.

\subsection{Health effects}

Cardoon varieties are considered rich sources of bioactive compounds and apart from food uses, most of the plant parts may be used for medicinal purposes. The broad therapeutic spectrum of cardoon could be associated with the various phenolic compounds that have been detected in flower heads and leaf parts of the plant, which probably act synergistically with additive pharmacological effects (Petropoulos et al., 2017c). The plant extracts of $C$. cardunculus var. scolymus possess hepatoprotective, anticarcinogenic, antioxidative, diuretic, choleretic, cholagogue, antidiabetic and antibacterial activities (Lattanzio et al., 2009). Plant tissue extracts and infusions exhibited significant in vitro antioxidant activities, whose potency depends on plant part and the extraction method (Kollia, Markaki, Zoumpoulakis, \& Proestos, 2016). Moreover, leaf extracts have been attributed with protective effects against HIV and bile discard, as well as with inhibitory activities against cholesterol biosynthesis and LDL oxidation (Lattanzio et al., 2009). The high content of cardoon in inulin has been associated with beneficial effects on gut microflora and minerals absorption, as well as with protective effects against colon cancer (Lattanzio et al., 2009).

\section{Eryngium maritimum L}

Sea holly (Eryngium maritimum L.) is a halophyte species of the Apiaceae family and one of the most important species belonging to Eryngium genus. It is a perennial herbaceous shrub which prefers saline conditions and low nitrogen availability (Clausing, Vickers, \& Kadereit, 2000). The species grows usually in sand hills, while it can be found along the coasts in Southern Europe (Lajnef, Pasini, Politowicz, Tlili, \& Khaldi, 2017), as well as in the Atlantic coasts of Europe and North Africa (Clausing et al., 2000). The edible parts of the species are its leaves and roots, while the aerial parts and roots have been traditionally used in folk medicine as remedies against various diseases (Lajnef et al., 2017; Lisciani et al., 1984). Moreover, Amessis-Ouchemoukh, Madani, Falé, Serralheiro, and Araújo (2014) highlighted the potential use of the species in the development of plant-derived drugs considering the increasing demands of the pharmaceutical industry and consumers preferences to such products. However, the commercial exploitation of the species has to be carried out with special care in order to avoid genetic erosion, since according to Bracchetti and Conti (2014) the species did not show great adaptability to the rapid changes that occurred during the last decade in the coastlines.

\subsection{Chemical composition}

Sea holly has a significant content of phenolic acids, being caffeic acid and gallic acid the major compounds (Mejri et al., 2017). Besides to these compounds several other constituents are also present, namely flavonoids (flavone, rutin trihydrat, quercetin dihydrat, kaempferol, apigenin, luteolin) and phenolic acids (rosmarinic acid, trans-hydroxycinnamic acid, trans-cinnamic acid, 4-Hydroxybenzoic acid, 3,5-Dimethoxy-4-hydroxybenzoic acid, syringic acid and salicylic acid) (Mejri et al., 2017). Moreover, Amessis-Ouchemoukh et al. (2014) reported differences in bioactive contents between leaves and stems, with leaves contain higher amounts of total phenolics, flavonoids, flavonols, proanthocyanidins and total tannins. E. maritimum seeds have also a rich oil content, which according to (Lajnef et al., 2018) ranged between 22.9 and $34.2 \%$, with the oleic acid being the main fatty acid (58.3\%-62.8\%). Recently, sixty-six volatile compounds, such as germacrene D (13.62-31.71\%), 15-hydroxy- $\alpha$-muurolene (12.04-18.58\%), and germacrene B (6.77-15.04\%) were also identified in the essential oils from air-dried seeds, representing from $32.4 \%$ to $65.3 \%$ of total volatiles content (Darriet, Andreani, Cian, Costa, \& Muselli, 2014). Apart from seeds, roots also contain essential oils, which according to Darriet et al. (2014) are rich in 2,4,5-trimethylbenzaldehyde and 2,3,6trimethylbenzaldehyde and $\alpha$-muurolene $(39.8,29.0$ and $23.5 \%$, respectively). In the same study, the essential oils composition of the separated aerial parts (flowers, stems and leaves) consisted mostly of germacrene D, $4 \beta \mathrm{H}$-muurol-9-en-15-al, $4 \beta \mathrm{H}$-cadin-9-en-15-al and $4 \beta \mathrm{H}$ cadin-9-en-15-ol (Darriet et al., 2014).

\subsection{Health effects}

Eryngium maritimum is also an important halophyte, since leaves extracts exhibited strong antioxidant activity and antibacterial activity against Pseudomonas aeruginosa and Pseudomonas fluorescens (MeotDuros, Le Floch, \& Magné, 2008), while Yurdakök and Baydan (2013) reported that extracts from the aerial and root parts showed cytotoxic effects against human hepatocellular carcinoma (HepG2) and human laryngeal epidermoid carcinoma (Hep2) cells. In a recent study, Amessis-Ouchemoukh et al. (2014) observed that leaves extracts exhibited significant acetylcholinesterase inhibitory activity, while stems had a stronger metal chelating activity than leaves. Also, interesting to highlight is that the extracts from the E. maritimum displayed anti-inflammatory and antinociceptive activities (Küpeli, Kartal, Aslan, \& Yesilada, 2006). Other therapeutic effects include nephroprotective, hepatoprotective and antifibrotic properties from seed methanolic extracts (Mejri et al., 2017), while Meot-Duros et al. (2008) reported several medicinal uses such as kidney stone formation inhibition and aphrodisiac, expectorant, diaphoretic, diuretic, stimulative, cystotonic, and anthelmintic properties.

\section{Inula crithmoides $\mathrm{L}$}

Golden samphire (Inula crithmoides L., syn. Limbarda crithmoides (L.) Dumort.) is a succulent dicotyledonous species commonly found in the Mediterranean basin (Zurayk \& Baalbaki, 1996). The salt tolerance of this species may be based on its ability to accumulate glycine betaine and proline for osmoregulatory purposes (Hassan, Estrelles, Soriano, Boscaiu, \& Vicente, 2017). Moreover, young leaves of the species are edible and exhibit various medicinal activities (Zurayk \& Baalbaki, 1996).

\subsection{Chemical composition}

Golden samphire present on their chemical composition a wide variety of molecules, among them the essential oil obtained from aerial parts have on their content hydrocarbons, such as 1-methylethyl-trimethylbenzene (18.7\%); monoterpene hydrocarbons (32.1\%), being $\alpha$ pinene the most abundant component, followed by $p$-cymene, $\beta$-phellandrene and $\alpha$-phellandrene (Fontana, Bruno, Senatore, \& Formisano, 2014). Phenols are also present (19.6\%), with thymol being the main component. Sesquiterpenes hydrocarbons (19.4\%) and oxygenated sesquiterpenes (12.0\%) are also part of the chemical composition of oil, with germacrene D (5.9\%) and t-cadinol (6.2\%) being the most abundant compounds (Fontana et al., 2014). Besides, scopoletin (15.3\%), phenolic compounds, such as rutin, syringic, ferulic, gallic and chlorogenic acids have also been reported as ingredients of the aerial 
parts of the species, as well as carotene derivatives, fatty acids, sesquiterpenes and other terpenoids compounds (Omezzine, Ladhari, Rinez, \& Haouala, 2011). The compounds 3,5-Dicaffeoylquinic acid and chlorogenic acid have been also isolated from aerial parts of $I$. crithmoides plants, as well as quercetin, $\alpha$-amyrin, $\beta$-sitosterol and $\beta$-sitosterol-3-O- $\beta$-D-glucopyranoside (Malash, Ibrahim, Ibrahim, Kabbash, \& El-Aasr, 2015). Also, interesting to highlight is that the chemical composition of this plant is highly affected by culture and harvesting conditions as also pronounced differences are observed between species obtained from distinct regions due to different growing conditions.

\subsection{Health effects}

Inula crithmoides is also an interesting antioxidant halophyte, acting as free radical's scavenger, reducing agent and even superoxide anion quencher (Jdey et al., 2017). In a recent study, Andreani et al. (2013) also reported that the essential oils of the aerial plat parts exhibited antioxidant activity. Significant anti-tyrosinase effects have also been evidenced, namely acting as inhibitor of diphenolase, while moderate effects were observed as monophenolase inhibitor (Jdey et al., 2017). According to Bucchini et al. (2015), the antifungal potential against Alternaria solani and Phytophthora cryptogea and fungistatic effects against Fusarium species were comparable with the activity of the positive control nystatin. Furthermore, this plant also exerts a pronounced antibacterial effect, both against Gram-positive ( $S$. aureus and Bacillus cereus) and Gram-negative species (Escherichia coli and Pseudomonas aeruginosa), being even the observed effect similar to those obtained by the positive control gentamycin (Jallali et al., 2014). Anticlastogenic and antimutagenic effects were also observed, being even proposed that the use of the aqueous plant extracts are safe and succeeded in counteracting the oxidative stress and protect against the cytotoxicity (Abdel-Wahhab, Abdel-Azim, \& El-Nekeety, 2008). The use of this halophytic plant as an herbicidal has been also proposed without affecting germination index of crop plants (Omezzine et al., 2011). Many medicinal uses have been confirmed through ethnopharmacological studies, since according to Lopes et al. (2016) and (Jallali et al., 2014) I. crithmoides is widely appreciated in traditional medicine for treatment of bronchitis, tuberculosis, anemia, as astringent, for malaria and diseases of urinary system, while the methanolic extracts from this species possess hepatoprotective activity (Malash et al., 2015).

\section{Lepidium latifolium $\mathrm{L}$}

Pepperwort or broaded pepperplant (Lepidium latifolium L., Brassicaceae) is a weed native in several Mediterranean countries, as well as in Northern America and Asia (Kaur, Hussain, Koul, Vishwakarma, \& Vyas, 2013). Pepperwort is a perennial plant which prefers moist areas, it has a height of $0.3-2 \mathrm{~m}$, woody stems, waxy leaves and small white flowers, while it produces a great number of seeds (Kaur, Bhat, \& Raina, 2013). It is also reported to have salt-tolerance properties through the glutathione induction of antioxidant enzymes (Dagar, Minhas, \& Kumar, 2011; Kaur, Bhat, et al., 2013). All the aerial parts of the plant are edible, while they also have medicinal uses. The species has gained great research interest during the last decades due to its invasive and competitive behavior in the habitats where it is present, mostly due to its ability to reflect solar radiation and consequently to reduce the available energy for photosynthetic purposes from the ecosystem and especially from other herbaceous plants (Sonnentag et al., 2011). This feature along with its perpetual reproduction through sexual (seeds) and asexual methods (root propagules) render the species a potential threat for the ecosystems and special care is required prior to its commercial exploitation.

\subsection{Chemical composition}

Pepperwort contains a wide variety of chemical constituents with bioactivities, among them Apetalumoside B6, Quercetin-3-O- $\beta$-d-sophoroside-7-O- $\alpha$-1-rhamnoside, Quercetin-3-O-(2,6-di-O- $\beta$-D-glucopyranosyl)- $\beta$-D-glucopyranoside-7-O- $\alpha$-L-rhamnopyranoside, Kaempferol7-O- $\alpha$-L-rhamnopyranoside and various Kaempferol derivatives (Xiang, Haixia, Lijuan, \& Yanduo, 2017). The leaves of L. latifolium also contain the epithionitrile1-cyano-2,3-epithiopropane (CETP; Conde-Rioll et al. (2017)). Moreover, leaves of pepperwort contains several glucosinolates such as glucoiberin, glucobrassicin, glucocherolin, glucoraphanin, sinigrin, gluconapin, glucotropeolin, and phenylethyl glucosinolate in amounts that differed between the tested ecotypes and plant parts (leaves and roots), while sinigrin was the most abundant one (Kaur, Bhat et al., 2013; Kaur, Hussain et al., 2013). Leaves contained higher amounts of phenols and flavonoids than roots, while fatty acids of leaves consisted mostly of linolenic, palmitic and stearic acid (Kaur, Hussain, et al., 2013).

\subsection{Health effects}

Regarding the medicinal properties of pepperwort, Conde-Rioll et al. (2017) observed that the extract from leaves of L. latifolium exhibited considerable in vitro antitumor activity against HT-29 human colon cancer cells which was directly attributed to the compound 1cyano-2,3-epithiopropane (CETP) that isolated in leaves extracts. According to Hanschen, Herz, Schlotz, and Kupke (2015), although firm results regarding apoptotic and selective toxic effects of CEPT against human cancer cells were not obtained, the authors suggested that antitumor activity should be attributed to inhibition of mitochondrial dehydrogenase activity of human hepatocellular carcinoma (HCC) cells. Ethanolic extracts of $L$. latifolium leaves also contain several natural antioxidants which exhibit significant free radical scavenging activity, especially compounds Quercetin-3-O- $\beta$ - D-sophoroside-7-O- $\alpha$-L-rhamnoside, Apetalumoside B6, Kaempferol-7-O- $\alpha$-L-rhamnopyranoside and Kaempferol-3-O- robinoside-7-O-(2"'"-(E)-feruloyl)-sophoroside (Xiang et al., 2017). Other health effects of the species include diuretic and hypotensive properties, and activities against prostate hyperplasia (Lisciani et al., 1984; Martínez Caballero, Carricajo Fernández, \& PérezFernández, 2004), as well as traditional uses against renal lithiasis and kidney disorders (Tabassum \& Ahmad, 2011).

\section{Plantago coronopus}

Plantains (Plantago sp.) belongs to Plantaginaceae family. Several species of this genus such as $P$. coronopus L., $P$. crassifolia Forssk. and $P$. maritima are commonly found in saline environments, while other species such as $P$. major are not salt-tolerant and damaged under high salinity conditions (Al Hassan, Pacurar, Gaspar, Vicente, \& Boscaiu, 2014). Gil, Lull, Boscaiu, Lidón, and Vicente (2011) reported that sorbitol may play a role in stress tolerance of $P$. crassifolia plants, while salt tolerance of $P$. maritima is associated with proline and antioxidant enzymes accumulation in leaves and roots, respectively (Sleimi, Guerfali, \& Bankaji, 2015). According to Neves, Matos, Moutinho, Queiroz, and Gomes (2009) the leaves and flowered part of $P$. coronopus are used in traditional medicine in Portugal, while leaves from other Plantago species can be also used for culinary purposes (Fig. $3 \mathrm{~g}$ ).

\subsection{Chemical composition}

Plantago species comprise the largest group of the Plantaginaceae family, containing a wide variety of chemical constituents, among them high contents of primary and secondary metabolites, namely phenolic acids (gallic acid, $p$-hydroxybenzoic acid, vanillic acid, syringic acid, salicylic acid, caffeic acid, coumaric acid, ferulic acid, rosmarinic acid and verbascoside), flavonoids (catechin, epicatechin, quercetin, flavone, luteolin-7-O-glucoside, luteolin, apigenin), coumarins, lignans, glycosides, triterpenes and polysaccharides that seems to be determinant to the widely recognized bioactive effects (Jdey et al., 2017). 
Beara et al. (2009) reported that $P$. coronopus has a high polyphenols, flavonoids, minerals, and amino acids content, while displays high antioxidant capacity. Also interesting to highlight is that the phenolic profile of Plantago spp. is highly dependent on the organ and extraction solvent used, as well as on the species (Beara et al., 2009). For example, in a study performed by Pereira et al. (2017b), roots presented the highest phenolic content and diversity in phenolic compounds, followed by flowers and leaves. Moreover, this species is also a valuable source of amino acids (arginine, leucine, lysine, phenylalanine, threonine, serine, proline, tyrosine and glycine) and minerals (sodium, calcium, potassium, magnesium and iron) (Pereira et al., 2017b), which may be a promissory factor to incite their upcoming use as an ingredient in human nutrition on a wider scale.

\subsection{Health effects}

Plantago coronopus is a medicinal halophyte with a wide variety of ethnomedicinal uses, although the scientific assessment of their biological activity is relatively scarce. More recently it has been reported a very interesting antioxidant capacity, mainly acting as a free radical's scavenger, chelating agent and even reducing power (Jdey et al., 2017). Furthermore, $P$. coronopus shown a capacity to inhibit the cholinesterase enzymes, monophenolase and diphenolase, which suggests their upcoming use as effective biomolecules towards new natural skinwhitening agents (Jdey et al., 2017). In fact, the recent data obtained has allowed to understand the main traditional uses given to this plant, which in turns emphasizes their potential as a source of biomolecules particularly useful to prevent multiple disorders, including those of oxidative stress-related diseases. The aerial parts and roots of the plant are widely used in folk medicine as anticancer, antimicrobial, antiviral, anti-inflammatory, analgesic, astringent, expectorant, diuretic, antipyretic, emollient agents and even in the treatment of upper respiratory disorders (Pereira et al., 2017b), while González-Tejero et al. (2008) reported its use against kidney and reproduction system disorders. Finally, Neves et al. (2009) described the skin protective and oral antiseptic uses of the aerial parts. Considering the great number of Plantago species, further studies should be performed in order to deepen knowledge on this field.

\section{Portulaca oleracea $\mathrm{L}$}

Common purslane (Portulaca oleracea L., Portulacaceae) is an important annual weed, native to the Mediterranean basin and widespread throughout the world (Karkanis \& Petropoulos, 2017). The edible parts of the species are its stems and leaves, which are used as salad vegetables and contain significant amounts of omega-3 fatty acids (Petropoulos et al., 2015; Petropoulos, Karkanis, Martins, \& Ferreira, 2016) (Fig. 3h). Its chemical composition and cultivation practices were reviewed recently in detail by Petropoulos, Karkanis, et al. (2016), where the nutritional value of the species was highlighted. However, in the study of Petropoulos et al. (2015) as well as in the review paper of Gonnella, Charfeddine, Conversa, and Santamaria (2010), the high content of edible parts in antinutrients such as oxalates was noted, a feature that has to be considered before further commercial exploitation of the species as a ready-to-use vegetable. Regarding its salt tolerance, common purslane is considered a moderately salt tolerant species, since it has the capacity to withstand up to $240 \mathrm{mM}$ of soil salinity (Kafi \& Rahimi, 2011), while Anastaćio and Carvalho (2013) did not observe toxicity symptoms under the same salinity levels in hydroponically grown purslane plants. In a recent study, Karakaş, Çullu, and Dikilitaş (2017) also reported that common purslane can be used for phytoremediation purposes to reduce the $\mathrm{Na}^{+}$and $\mathrm{Cl}^{-}$concentrations in saline soils. This species is also used in traditional medicine for the treatment of several diseases (Ramadan, Schaalan, \& Tolba, 2017).

\subsection{Chemical composition}

Common purslane is widely known as one of the richest plant source of omega- 3 fatty acids, although several fatty acids have been also detected, namely, $\alpha$-linolenic acid, followed by palmitoleic, palmitic, linoleic, oleic and stearic acids (Uddin et al., 2014). Moreover, according to Anastaćio and Carvalho (2013), salinity levels resulted in changes of relative percentage of the main fatty acids (palmitic, $\alpha$-linolenic and linoleic acid) without however affecting $\omega 6 / \omega 3$ ratio. The carotenoids $\alpha$ - and $\beta$-carotene, lutein and zeaxanthin are also abundant in purslane, with important bioactive properties being attributed to these compounds (Dias, Camões, \& Oliveira, 2009). Tocopherols, vitamin C and some vitamers of complex-B (B1 - thiamine, B2 - riboflavin, B3 - niacin, B5 - pantothenic acid, B6 - pyridoxine, and B9 - folates) have also been identified in purslane, as also relatively high contents of oxalic acid and minerals, such as iron (Fe), zinc (Zn), potassium (K), boron $(B)$, nitrogen $(\mathrm{N})$, manganese $(\mathrm{Mn})$, calcium $(\mathrm{Ca})$, copper $(\mathrm{Cu})$, magnesium (Mg), and slightly lower amounts of phosphorus (P), sulfur (S), sodium (Na) (Alam et al., 2014). Besides to the above referred bioactive constituents, different types of alkaloids (oleraceins A-E, betalain alkaloid pigments - reddish betacyanins and yellow betaxanthins), mucilages and pectins, flavonoids (apigenin, kaempferol, luteolin, quercetin, myricetin, genistein, genistin, portulacanones A-D), phenolic acids (caffeic, chlorogenic, $p$-coumaric, ferulic and rosmarinic acids), lignins, stilbenes, terpenoids, saponins, tannins, chlorophyll, bergapten and robustin have been also detected (Erkan, 2012). Finally, it has to be mentioned that the chemical composition of purslane shows a seasonal variation, while it also varied depending on growing and harvesting conditions and plant part (Alam et al., 2015).

\subsection{Health effects}

Portulaca oleracea is an omnipresent halophyte that displays promising antioxidant properties, mainly acting as free radical scavenger, metal quencher, lipid peroxidation inhibitor and even significant DNA protectant against hydroxyl radicals (Alam et al., 2014). The antimutagenic potency of this plant was also investigated, and directly correlated with the antioxidant potential conferred by various phytochemicals present in plant tissues (YouGuo, ZongJi, \& XiaoPing, 2009). Some of these biomolecules, namely phenolic constituents are also able to promote cardiovascular function, mainly acting as anti-inflammatory and anti-nociceptive agents, at same that reduce the human cancer risk (Ramadan et al., 2017). Linked with these effects, anti-atherogenic, anti-hyperlipidemic, and hepatoprotective benefits may be also reached, at same time that pronounced improvements in kidney and nervous system have been stated (Chowdhary, Meruva, Naresh, \& Elumalai, 2013). Furthermore, promising antispasmodic, anti-arthritic, antidiabetic, antiseptic, diuretic, antimicrobial, vermifuge, tonic and febrifuge potentialities have been also reported, besides their unquestionable action as an immunomodulatory agent (Chen, Li, Zhang, Xia, \& Zhang, 2016). P. oleracea extracts may also stimulate the signaling in $\beta$ cells and thus can be used for diabetes prevention (Ramadan et al., 2017). In addition, extract of this species inhibited the acetylcholinesterase (AChE) enzyme, which is a key target in Alzheimer's disease treatment (Chen et al., 2016). According to these researchers, this activity may be due to compounds dopamine and norepinephrine that are present in $P$. oleraceae ethanolic extracts. Apart from its beneficial effects common purslane is considered to contain great amounts of oxalic acid which may has severe implications on human health, especially to people that have a tendency to kidney stone formation. However, according to (Petropoulos et al., 2015) oxalic acid content is a genotype dependent feature and could be minimized through genotype selection and breeding techniques and incite commercial cultivation and consumption on a regular basis. 


\section{Salicornia herbacea L}

Grasshort (Salicornia herbacea L., Amaranthaceae) is an edible halophytic species commonly found in salt marches (Kim et al., 2017). According to Lee, Kim, Kim, and Sohn (2016) this species can withstand $100 \mathrm{mM}$ of $\mathrm{NaCl}$, through the accumulation of shikimic acid, vitamin $\mathrm{K} 1$, and indole-3-carboxylic acid in root system as a primary response to salinity stress. Ermawati et al. (2009) also reported that the gene ShTIP (Salicornia herbacea tonoplast intrinsic protein) was highly expressed in the shoots and roots under salt stress conditions which indicate its involvement in salt tolerance mechanisms through ionic transport regulation. The aerial parts of the plant are edible and eaten as seasoned vegetable in many Mediterranean countries (Ksouri et al., 2012), while Zhao, Wang, Wang, Liu, and Xin (2014) have suggested the use of glasswort powder for the production of a novel vinegar with anti-fatigue effects.

\subsection{Chemical composition}

Several caffeoylated quinic acid derivatives (CQAs) such as 3-OCaffeoyl-5-O-dihydrocaffeoyl quinic acid, 4,5-di-O-dihydrocaffeoyl quinic acid and 3,5-di-O-caffeoyl quinic acid were isolated from methanolic extracts of the aerial parts of $S$. herbacea, as well as flavonol glucosides such as quercetin 3-O- $\beta$-d-glucopyranoside, isorhamnetin 3-O- $\beta$-D-glucopyranoside and isoquercitrin 6"-O-methyloxalate (Cho et al., 2016). More recently, two new triterpene saponins salbige A and salbige B and other already reported compounds such as echinocystic acid, gypsogenin and pheophorbide A were identified in methanolic extracts of the aerial parts of Salicornia herbacea (Zhao et al., 2014). Kim et al. (2012) isolated three already known saponins and one newly found triterpenoid saponin 3bhydroxy-23-oxo-30-noroleana- 12,20(29)-diene-28-oic acid 3-O-b-D-glucuronopyranosyl-28-O-b- D-glucopyranoside. According to Kim, Cho, et al. (2014) and Kim, Jun, et al. (2014), phenylpropanoic acids and flavonols content depends on growth stage with higher contents being detected at maturity stage. Other reported compounds include pentadecyl ferulate, phytol, stearolic acid, (3Z,6Z,9Z)-tricosa-3,6,9-triene, stigmasterol, ergosterol, dioctyl phthalate, dibutyl phthalate, vanillic aldehyde, and scopoletin (Wang et al., 2013). Fatty acids of stems consist mainly of linoleic and linolenic acids, while palmitic and stearic acids were detected in lower amounts (Essaidi et al., 2013).

\subsection{Health effects}

Salicornia herbacea contains several bioactive compounds which have been associated with various medicinal properties. In a recent study, Kang et al. (2014) reported that the seed extracts of $S$. herbacea exhibit cytotoxic effects on HCT 116 and HT-29 colon cancer cells, while Lee et al. (2016) suggested the use of seed extracts as potential anti-coagulation agents. Tuan et al. (2015) found that the extract of $S$. herbacea possess anti-HMGB1 (high mobility group box 1 protein) activity, while some compounds isolated from the aerial parts of this species exhibited vascular protective activity against HMGB1 induced inflammatory reaction. Compounds such as salbige A and salbige B which have been isolated from the aerial plant parts of the species exhibited antiproliferative activities, while pheophorbide possessed inhibitory activity against A549 and HepG2 cancer cells (Zhao et al., 2014). Dicaffeoylquinic acid derivatives and flavonoid glucosides have been attributed with several health promoting bioactivities due to their high antioxidant potency, including neuroprotective, anti-inflammatory, antiadipogenic, hepatoprotective, skin whitening, antihypelipidemic and antibacterial effects (Choi, Kang, \& Hong, 2016; Essaidi et al., 2013; Kim, Jun, \& Kim, 2014; Tuan et al., 2015). Moreover, Ksouri et al. (2012) has reported biological effects such as hepatoprotective properties and inhibitory effects against oxidation-induced cellular damage, as well traditional medicinal uses against constipation, diabetes, obesity and cancer.

\section{Salsola soda $\mathrm{L}$}

Opposite-leaved saltwort (Salsola soda L., Chenopodiaceae) is an annual species native to several Mediterranean countries (Polat \& Sat1l, 2012). It is a halophytic succulent shrub that can be used for bio-desalination of saline soils and as a companion plant with conventional crops, while its leaves are edible and commonly used as raw or cooked salad vegetables (Colla, Rouphael, Fallovo, Cardarelli, \& Graifenberg, 2006). Apart from grown in the wild, $S$. soda has been introduced as a commercial cash crop with important high added value products, while in Italy is commonly known as 'agretti' vegetable (Centofanti \& Bañuelos, 2015).

\subsection{Chemical composition}

Opposite-leaved saltwort or barilla plant contains several bioactive compounds including flavonoids (isorhamnetin-3-O-glucoside and isorhamnetin-3-O-rutinoside), acetophenones, coumarins, sterols as also simple tetrahydroisoquinoline alkaloids, such as salsoline, salsolidine, $N$-Methylisosalsoline and carnegine, with very interesting phytopharmacological effects being attributed to these molecules (Tundis et al., 2009). Minerals, such as aluminium (Al), cobalt (Co), chromium $(\mathrm{Cr})$, copper $(\mathrm{Cu})$, iron $(\mathrm{Fe})$, manganese $(\mathrm{Mn})$, nickel $(\mathrm{Ni})$, zinc $(\mathrm{Zn})$, selenium (Se) and boron (B) are also present in $S$. soda aerial parts, being even observed marked differences in mineral composition of leaves, stems and roots (Centofanti \& Bañuelos, 2015).

\subsection{Health effects}

Salsola soda is a halophyte with a very interesting antidiabetic potential, since it has been attributed with inhibitory effects against $\alpha$ amylase enzyme, probably due to its high content in phenolic compounds, namely flavonol glycosides (Tundis, Loizzo, Statti, \& Menichini, 2007). Also, in the study performed by Tundis et al. (2009), promissory antioxidant effects were also reached using an alkaloid extract from the aerial parts of the plant, mainly acting as free radical's scavenger. Furthermore, the same authors also evaluated the role of plant extracts for Alzheimer's disease treatment through the assessment of the anti-cholinesterase activity of this matrix, finding both acetylcholinesterase (AChE) and butyrylcholinesterase (BChE) inhibitory effects, mainly conferred by its chemical constituents tetrahydroisoquinoline alkaloids (Tundis et al., 2009). The observed anticholinesterase effects present a dose-response relationship, i.e. different quantitative composition of bioactive constituents modified the final biological activities. According to Polat and Sat1l (2012) the aerial parts of $S$. soda are used for medicinal purposes in Turkey, while Tundis et al. (2009) reported that the extracts from the aerial parts of some Salsola species (S. oppositofolia, S. soda and S. tragus) exhibited significant antioxidant activity. Moreover, Loizzo, Calabria, Tundis, Calabria, and Pisa (2007) observed that the extracts of this species exhibited antihypertensive properties through the inhibition of angiotensin converting enzymes.

\section{Suaeda fruticosa Forssk}

Shrubby seablight (Suaeda fruticosa Forssk.) is a halophytic species of the Amaranthaceae family. This species is commonly found in moist areas with high salinity, $\mathrm{pH}, \mathrm{Na}$ and $\mathrm{Cl}$ (Chenchouni, 2017), while $S$. fruticosa plants can withstand salinity levels up to $300 \mathrm{mM} \mathrm{NaCl}$ through the increase of sugars, proline and proteins content (Hameed et al., 2012). According to Devi et al. (2016) this species is a salt hyperaccumulator and can be used for phytoremediation of saline soils. Regarding the nutritional value of $S$. frtuticosa, its seeds contains about $25 \%$ oil that can be used for human consumption, while its leaves are edible and used for human consumption or as forage (Weber, Ansari, Gul, \& Ajmal Khan, 2007). 


\subsection{Chemical composition}

Shrubby seablight is a halophytic plant with a varied chemical composition of fatty acids, such as linoleic and oleic acids, followed by palmitic and stearic acids (Ozcan, 2014); minerals (aluminium, calcium, phosphorus, potassium, magnesium, iron, manganese, copper and zinc, and relatively lower contents of cobalt, chromium and nickel) (Towhidi, Saberifar, \& Dirandeh, 2011). Pronounced amounts of phenols, flavonoids (gallic acid, catechin, chlorogenic acid, caffeic acid, quercetin and kaempferol), tannins, proanthocyanidins, carotenoids, alkaloids and saponins have been also detected (Oueslati et al., 2012a; Qasim et al., 2017), which have been direct associated with the phytopharmacological potential of the species.

\subsection{Health effects}

Suaeda fruticosa exhibits several bioactive effects which are attributed to its high phenolic compounds content. Promissory in vitro and ex vivo antioxidant properties were also reported by Oueslati et al. (2012b), who found that $S$. fruticosa displayed both free radicals scavenging, lipid peroxidation inhibition and oxidation prevention effects. Furthermore, the authors also revealed that 2,5-dihydroxybenzoic acid and rutin hydrate were the major molecules, and concluded that the effectiveness of the extract is highly depended on the content of these bioactive molecules. Similar findings were also stated by Qasim et al. (2017), in a detailed study aiming to assess the antioxidant capacity, phenolic composition and bioactive compounds of $S$. fruticosa and other medicinal halophytes commonly used as herbal teas. In addition, the authors highlighted that the species showed strong radical scavenging and reducing power capacities, which were higher than synthetic positive controls (Qasim et al., 2017). Further, and not least important to point out is that this plant is also used in traditional medicine as an effective hypoglycemic and anti-hyperlipidemic agent (Benwahhoud, Jouad, Eddouks, \& Lyoussi, 2001), while Ksouri et al. (2012) reported that dichloromethane extracts of $S$. fruticosa exhibited significant anticancer activity against human lung carcinoma and colon adenocarcinoma cell lines.

\section{Tribulus terrestris $\mathrm{L}$}

Puncturevine (Tribulus terrestris L., Zygophyllaceeae) is an important weed commonly found in sandy soils throughout the Southern Europe, while it is considered moderately salt tolerant (Šalamon, Grul'ová, \& Feo, 2016) (Fig. 3i). It is a widely distributed species and a basic ingredient in folk medicine with several uses against various human conditions (Hammoda et al., 2013). Recently, there are available several dietary supplements with $T$. terrestris as the basic ingredient, based on health claims regarding its aphrodisiac and testosterone production enhancing properties (Antonio, Uelmen, Rodriguez, \& Earnest, 2000; Gonçalves, Aguiar, \& Wolff, 2017). Moreover, Šalamon et al. (2016) evaluated the potential of commercial growing of puncturevine and suggested that transplantation of seedlings was more effective than direct sowing in terms of both biomass production and bioactive compounds content.

\subsection{Chemical composition}

Puctuverine contains protodioscin and several other furostanol saponins which have been isolated from the aerial parts of the plant (De Combarieu, Fuzzati, Lovati, \& Mercalli, 2003). Moreover, Wang, Zu, and Jiang (2009) isolated in extracts of T. terrestris several constituents including terrestriamide, quercetin-3-O- $\beta$-D-glucoside, hecogenin -3-O$\beta$-D-glucopyranosyl (1-4)- $\beta$-D-galactopyranoside, and uridine. Sixteen steroidal saponins have been isolated from hydroethanolic extracts fo the aerial parts of the plant, including seven newly reported compounds including terrestrinin C, D and E (Kang et al., 2014). Other reported compounds include two oligosaccharides and the stereoisomer of di-pcoumaroylquinic acid; 4,5-di-p-cis-coumaroylquinic acid (Hammoda et al., 2013).

\subsection{Health effects}

Puncturevine is one of the most researched aphrodisiac plants known as "plant Viagra", with its therapeutic properties being attributed to the presence of furostanol saponins (Šalamon et al., 2016). Protodioscin is the main phytochemical compound in T. terrestris plants and is suggested to stimulate the production of testosterone in men, while women with hypoactive sexual desire disorder (HSSD) who received T. terrestris exhibited increased levels of testosterone (Vale, Zanolla Dias de Souza, Rezende, \& Geber, 2017). In contrast, Antonio et al. (2000) reported that oral administration of tribulus (a herbal preparation of $T$. terrestris) at a dose of $3.21 \mathrm{mg} \mathrm{kg}^{-1}$ body weight, had no significant effect on body composition or exercise performance in resistance-trained subjects. However, Ma, Guo, and Wang (2017) suggested that $T$. terrestris extracts did not increase body mass and testosterone levels, but they increased anaerobic performance of trained boxers and gave relief to muscle damage through the decrease of IGF binding protein-3 in plasma. Several other constituents of T. terrestris exert medicinal properties. In a recent study, Wei et al. (2014) reported that the terrestrosin D inhibited the growth and angiogenesis of prostate cancer cells and endothelial cells. Further, and not least important to point out is that this plant has also exhibited antioxidant activity, with 5-di-p-trans-coumaroylquinic acid being responsible for this activity (Hammoda et al., 2013).

\section{Conclusion and future perspectives}

Wild halophyte species of the Mediterranean basin are considered a valuable genetic source with great adaptation to severe conditions such as soil and irrigation water salinity that could be used as alternative cash crops in a saline agriculture regime. Moreover, the diversified and increased content in bioactive compounds render these species as very promising candidates for the food industry in order to design and produce novel food products with functional and health beneficial properties, such as beverages, leafy salads, microencapsulated oils, food additives, antimicrobial agents etc. However, a multi-step approach has to be implemented before these products become commercially available including: a) the evaluation of various ecotypes of the candidate species in order to select those with the most promising properties, b) the integration of selected genotypes in breeding programs for further improvement of selected features, e.g. enhanced bioactivity and bioactive compounds content, improved agronomic features, decreased content of possible antinutrients, c) the evaluation of cultivation practices to find the most suitable and purpose made practice guides d) the assessment of bioactive compounds content under commercial cultivation conditions, e) extended clinical and model trials to determine the health effects mechanisms, the recommended consumption on a daily basis, to exclude possible toxicity effects, e) the design and marketing of novel food products from halophytes, f) the shaping up of alternative approaches for healthy diets and well-being and the increase of consumer awareness, and g) the legislation regarding consumers safety issues and genetic conservation of the halophyte species.

\section{References}

Abdel-Wahhab, M. A., Abdel-Azim, S. H., \& El-Nekeety, A. A. (2008). Inula crithmoides extract protects against ochratoxin A-induced oxidative stress, clastogenic and mutagenic alterations in male rats. Toxicon, 52(4), 566-573. https://doi.org/10.1016/j. toxicon.2008.07.006.

Aichi-Yousfi, H., Meddeb, E., Rouissi, W., Hamrouni, L., Rouz, S., Rejeb, M. N., et al. (2016). Phenolic composition and antioxidant activity of aqueous and ethanolic leaf extracts of six Tunisian species of genus Capparis - Capparaceae. Industrial Crops and Products, 92, 218-226. https://doi.org/10.1016/j.indcrop.2016.07.051. 
Akkari, H., B'Chir, F., Hajaji, S., Rekik, M., Sebai, E., Hamza, H., et al. (2016). Potential anthelmintic effect of Capparis spinosa ( Capparidaceae) as related to its polyphenolic content and antioxidant activity. Veterinarni Medicina, 61(6), 308-316. https://doi. org/10.17221/169/2015-VETMED.

Al Hassan, M., Pacurar, A., Gaspar, A., Vicente, O., \& Boscaiu, M. (2014). Growth and reproductive success under saline conditions of three Plantago species with different levels of stress tolerance. Notulae Botanicae Horti Agrobotanici Cluj-Napoca, 42(1), 180-186. https://doi.org/10.15835/nbha4219349.

Alam, M. A., Juraimi, A. S., Rafii, M. Y., Abdul Hamid, A., Aslani, F., Hasan, M. M., et al. (2014). Evaluation of antioxidant compounds, antioxidant activities, and mineral composition of 13 collected purslane (Portulaca oleracea L.) accessions. BioMed Research International, 2014, 6-10. https://doi.org/10.1155/2014/296063.

Alam, M. A., Juraimi, A. S., Rafii, M. Y., Hamid, A. A., Arolu, I. W., \& Latif, M. A. (2015) Genetic diversity analysis among collected purslane (Portulaca oleracea L.) accessions using ISSR markers. Comptes Rendus Biologies, 338(1), 1-11. https://doi.org/10. 1016/j.crvi.2014.10.007.

Amessis-Ouchemoukh, N., Madani, K., Falé, P. L. V., Serralheiro, M. L., \& Araújo, M. E. M. (2014). Antioxidant capacity and phenolic contents of some Mediterranean medicinal plants and their potential role in the inhibition of cyclooxygenase- 1 and acetylcholinesterase activities. Industrial Crops and Products, 53, 6-15. https://doi.org/10. 1016/j.indcrop.2013.12.008.

Anastaćio, A., \& Carvalho, I. S. (2013). Accumulation of fatty acids in purslane grown in hydroponic salt stress conditions. International Journal of Food Science and Nutrition, 64(2), 235-242. https://doi.org/10.3109/09637486.2012.713915.

Andreani, S., De Cian, M. C., Paolini, J., Desjobert, J. M., Costa, J., et al. (2013). Chemical variability and antioxidant activity of Limbarda crithmoides L. essential oil from Corsica. Chemistry and Biodiversity, 10(11), 2061-2077. https://doi.org/10.1002/ cbdv.201300109.

Antonio, J., Uelmen, J., Rodriguez, R., \& Earnest, C. (2000). The effects of Tribulus terrestris on body composition and exercise performance in resistance-trained males. International Journal of Sport Nutrition and Exercise Metabolism. https://doi.org/10. 1123/ijsnem.10.2.208

Anwar, F., Muhammad, G., Hussain, M. A., Zengin, G., \& Alkharfy, K. M. (2016). Review article Capparis spinosa L: A plant with high potential for development of functional foods and nutraceuticals/pharmaceuticals. International Journal of Pharmacology, 12(3), 201-219. https://doi.org/10.3923/ijp.2016.201.219.

Argentieri, M., Macchia, F., Papadia, P., Paolo, F., \& Avato, P. (2012). Bioactive compounds from Capparis spinosa subsp. rupestris. Industrial Crops and Products, 36(1), 65-69. https://doi.org/10.1016/j.indcrop.2011.08.007.

Atia, A., Debez, A., Barhoumi, Z., \& Abdelly, C. (2010). Localization and composition of seed oils of Crithmum maritimum L. (Apiaceae ). African Journal of Biotechnology, 9(39), 6482-6485. https://doi.org/10.5897/AJB10.724.

Azhary, K. El, Tahiri Jouti, N., El Khachibi, M., Moutia, M., Tabyaoui, I., El Hou, A., et al. (2017). Anti-inflammatory potential of Capparis spinosa L. in vivo in mice through inhibition of cell infiltration and cytokine gene expression. BMC Complementary and Alternative Medicine, 17(1), 81. https://doi.org/10.1186/s12906-017-1569-7.

Bakr, R. O., \& Bishbishy, M. H. El (2016). Profile of bioactive compounds of Capparis spinosa var. aegyptiaca growing in Egypt. Brazilian Journal of Pharmacognosy, 26(4), 514-520. https://doi.org/10.1016/j.bjp.2016.04.001.

Beara, I. N., Lesjak, M. M., Jovin, E. D., Balog, K. J., Anačkov, G. T., Orčic, D. Z., et al (2009). Plantain (Plantago L.) species as novel sources of flavonoid antioxidants. Journal of Agricultural and Food Chemistry, 57, 9268-9273. https://doi.org/10.1021/ jf902205m.

Ben Amor, N., Ben Hamed, K., Debez, A., Grignon, C., \& Abdelly, C. (2005). Physiological and antioxidant responses of the perennial halophyte Crithmum maritimum to salinity. Plant Science, 168(4), 889-899. https://doi.org/10.1016/j.plantsci.2004.11. 002 .

Benwahhoud, M., Jouad, H., Eddouks, M., \& Lyoussi, B. (2001). Hypoglycemic effect of Suaeda fruticosa in streptozotocin-induced diabetic rats. Journal of Ethnopharmacology, 76, 35-38.

Beyrouthy, E., Nelly, A., Annick, D., \& Frederic, D. (2008). Plants used as remedies antirheumatic and antineuralgic in the traditional medicine of Lebanon. Journal of Ethnopharmacology, 120, 315-334. https://doi.org/10.1016/j.jep.2008.08.024.

Bharucha, Z., \& Pretty, J. (2010). The roles and values of wild foods in agricultural systems. Philosophical Transactions of the Royal Society B, 365, 2913-2926. https:// doi.org/10.1098/rstb.2010.0123.

Bianco, V. V., Santamaria, P., \& Elia, A. (1998). Nutritional value and nitrate content in edible wild species used in southern Italy. Acta Horticulturae, 467(December 2015), 71-87. https://doi.org/10.17660/ActaHortic.1998.467.7.

Bracchetti, L., \& Conti, F. (2014). Monitoring of threatened plants in the "sentina" natural reserve (marche, Italy). Plant Sociology, 51(2), 39-46. https://doi.org/10.7338/ pls2014512S1/05.

Brieudes, V., Angelis, A., Vougogiannopoulou, K., Pratsinis, H., Kletsas, D., Mitakou, S., et al. (2016). Phytochemical analysis and antioxidant potential of the phytonutrientrich decoction of Cichorium spinosum and cintybus. Planta Medica, 82(11-12), 1070-1078. https://doi.org/10.1055/s-0042-107472.

Bucchini, A., Ricci, D., Messina, F., Marcotullio, M. C., Curini, M., \& Giamperi, L. (2015). Antioxidant and antifungal activity of different extracts obtained from aerial parts of Inula crithmoides L. Natural Product Research, 29(12), 1173-1176. https://doi.org/ 10.1080/14786419.2014.983102.

Burczyk, J., Wierzchowska-Renke, K., Glowniak, K., Glowniak, P., \& Marek, D. (2002). Geographic and environmental influences on the variation of essential oil and coumarins in Crithmum maritimum L. Journal of Herbs, Spices, \& Medicinal Plants, 9(4), 305-311. https://doi.org/10.1300/J044v09n04_07.

Ceccarelli, N., Curadi, M., Picciarelli, P., Martelloni, L., Sbrana, C., \& Giovannetti, M. (2010). Globe artichoke as a functional food. Mediterranean Journal of Nutrition and
Metabolism, 3(3), 197-201. https://doi.org/10.1007/s12349-010-0021-z.

Centofanti, T., \& Bañuelos, G. (2015). Evaluation of the halophyte Salsola soda as an alternative crop for saline soils high in selenium and boron. Journal of Environmental Management, 157, 96-102. https://doi.org/10.1016/j.jenvman.2015.04.005.

Chedraoui, S., \& Rajjou, L. (2017). Capparis spinosa L. in A Systematic review: A xerophilous species of multi values and promising potentialities for agrosystems under the threat of global warming. Frontiers in Plant Science, 8(October), 1-18. https://doi. org/10.3389/fpls.2017.01845.

Chenchouni, H. (2017). Edaphic factors controlling the distribution of inland halophytes in an ephemeral salt lake "Sabkha ecosystem " at North African semi-arid lands. The Science of the Total Environment, 575, 660-671.

Chen, Y.-X., Li, G.-Z., Zhang, B., Xia, Z.-Y., \& Zhang, M. (2016). Molecular evaluation of herbal compounds as potent inhibitors of acetylcholinesterase for the treatment of Alzheimer's disease. Molecular Medicine Reports, 14, 446-452. https://doi.org/10. 3892/mmr.2016.5244.

Choi, Y. M., Kang, S., \& Hong, J. (2016). Modulation of the inflammatory process and interaction of THP-1 monocytes with intestinal epithelial cells by glasswort (Salicornia herbacea L.) extracts. Korean Journal of Food Science and Technology, 48(4), 373-383.

Cho, J.-Y., Kim, J. Y., Lee, Y. G., Lee, H. J., Shim, H. J., Lee, J. H., et al. (2016). Four new dicaffeoylquinic acid derivatives from glasswort ( Salicornia herbacea L.) and their. Molecules, 21(1097), 1-13. https://doi.org/10.3390/molecules21081097.

Chowdhary, C. V., Meruva, A., Naresh, K., \& Elumalai, R. K. A. (2013). A review on phytochemical and pharmacological profile of Portulaca oleracea linn. (Purslane). International Journal of Research in Ayurveda and Pharmacy, 4(1), 34-37. https://doi. org $/ 10.7897 / 2277-4343.04119$.

Clausing, G., Vickers, K., \& Kadereit, J. W. (2000). Historical biogeography in a linea system: Genetic variation of sea rocket (Cakile maritima) and sea holly (Eryngium maritimum) along European coasts. Molecular Ecology, 9(11), 1823-1833.

Colla, G., Rouphael, Y., Cardarelli, M., Svecova, E., Rea, E., \& Lucini, L. (2013). Effects of saline stress on mineral composition, phenolic acids and flavonoids in leaves of artichoke and cardoon genotypes grown in floating system. Journal of the Science of Food and Agriculture, 93(5), 1119-1127. https://doi.org/10.1002/jsfa.5861.

Colla, G., Rouphael, Y., Fallovo, C., Cardarelli, M., \& Graifenberg, A. (2006). Use of Salsola soda as a companion plant to improve greenhouse pepper (Capsicum annuum) performance under saline conditions. New Zealand Journal of Crop and Horticultural Science, 34(4), 283-290. https://doi.org/10.1080/01140671.2006. 9514418.

Conde-Rioll, M., Gajate, C., Fernandez, J. J., Villa-Pulgarin, J. A., Napolitano, J. G., Norte, M., et al. (2017). Antitumor activity of Lepidium latifolium and identification of the epithionitrile 1-cyano-2,3-epithiopropane as its major active component. Molecular Carcinogenesis, (October), 1-14. https://doi.org/10.1002/mc.22759.

Dagar, J., Minhas, P., \& Kumar, M. (2011). Cultivation of medicinal and aromatic plants in saline environments. CAB Reviews: Perspectives in Agriculture, Veterinary Science, Nutrition and Natural Resources, 6(9), 1-11. https://doi.org/10.1079/ PAVSNNR20116009.

Darriet, F., Andreani, S., Cian, M. De, Costa, J., \& Muselli, A. (2014). Chemical variability and antioxidant activity of Eryngium maritimum L. essential oils from Corsica and Sardinia. Flavour and Fragrance Journal, 29, 3-13. https://doi.org/10.1002/ffj.3160.

De Combarieu, E., Fuzzati, N., Lovati, M., \& Mercalli, E. (2003). Furostanol saponins from Tribulus terrestris. Fitoterapia, 74, 583-591. https://doi.org/10.1016/S0367-326X (03)00152-7.

Devi, S., Nandwal, A. S., Angrish, R., Arya, S. S., Kumar, N., \& Sharma, S. K. (2016). Phytoremediation potential of some halophytic species for soil salinity. International Journal of Phytoremediation, 18(7), 693-696. https://doi.org/10.1080/15226514. 2015.1131229.

Dias, M. G., Camões, M. F. G. F. C., \& Oliveira, L. (2009). Carotenoids in traditional Portuguese fruits and vegetables. Food Chemistry, 113(3), 808-815. https://doi.org/ 10.1016/j.foodchem.2008.08.002.

Erkan, N. (2012). Antioxidant activity and phenolic compounds of fractions from Portulaca oleracea L. Food Chemistry, 133(3), 775-781. https://doi.org/10.1016/j. foodchem.2012.01.091.

Ermawati, N., Liang, Y. S., Cha, J. Y., Shin, D., Jung, M. H., Lee, J. J., et al. (2009). A new tip homolog, ShTIP, from Salicornia shows a different involvement in salt stress compared to that of TIP from Arabidopsis. Biologia Plantarum, 53(2), 271-277. https://doi.org/10.1007/s10535-009-0050-y.

Essaidi, I., Brahmi, Z., Snoussi, A., Ben, H., Koubaier, H., Casabianca, H., et al. (2013). Phytochemical investigation of Tunisian Salicornia herbacea L., antioxidant, antimicrobial and cytochrome P450 (CYPs) inhibitory activities of its methanol extract. Food Control, 32(1), 125-133. https://doi.org/10.1016/j.foodcont.2012.11.006.

Fernández, J., Curt, M. D., \& Aguado, P. L. (2006). Industrial applications of Cynara cardunculus L. for energy and other uses. Industrial Crops and Products, 24(3), 222-229. https://doi.org/10.1016/j.indcrop.2006.06.010.

Fontana, G., Bruno, M., Senatore, F., \& Formisano, C. (2014). Volatile constituents of aeria parts of two Mediterranean species of Inula: Inula crithmoides L. and I. verbascifolia (Willd.) Hausskn. (Asteraceae). Natural Product Research. Taylor \& Francishttps:// doi.org/10.1080/14786419.2014.902821.

Gil, R., Lull, C., Boscaiu, M., Lidón, A., \& Vicente, O. (2011). Soluble carbohydrates as osmolytes in several halophytes from a mediterrannean salt marsh. Notulae Botanicae Horti Agrobotanici Cluj-Napoca, 39(2), 9-17.

Gonnella, M., Charfeddine, M., Conversa, G., \& Santamaria, P. (2010). Purslane: A review of its potential for health and agricultural aspects. The European Journal of Plant Science and Biotechnology, 4(1), 131-136.

González-Tejero, M. R., Casares-Porcel, M., Sánchez-Rojas, C. P., Ramiro-Gutiérrez, J. M., Molero-Mesa, J., Pieroni, A., et al. (2008). Medicinal plants in the Mediterranean area: Synthesis of the results of the project Rubia. Journal of Ethnopharmacology, 
116(2), 341-357. https://doi.org/10.1016/j.jep.2007.11.045.

Gonçalves, R. M. S. M. H. M. E., Aguiar, A. C. M. J. G., \& Wolff, P. (2017). Effect of oral administration of Tribulus terrestris extract on semen quality and body fat index of infertile men. Andrologia, 49, 1-6. https://doi.org/10.1111/and.12655.

Guarrera, P. M., \& Savo, V. (2013). Perceived health properties of wild and cultivated food plants in local and popular traditions of Italy: A review. Journal of Ethnopharmacology, 146, 659-680.

Guil, J. L., Rodríguez-García, I., \& Torija, E. (1997). Nutritional and toxic factors in selected wild edible plants. Plant Foods for Human Nutrition, 51, 99-107.

Hameed, A., Hussain, T., Gulzar, S., Aziz, I., Gul, B., \& Khan, M. A. (2012). Salt tolerance of a cash crop halophyte Suaeda fruticosa: Biochemical responses to salt and exogenous chemical treatments. Acta Physiologiae Plantarum, 34(6), 2331-2340. https:// doi.org/10.1007/s11738-012-1035-6.

Hammoda, H. M., Ghazy, N. M., Harraz, F. M., Radwan, M. M., Elsohly, M. A., \& Abdallah, I. I. (2013). Chemical constituents from Tribulus terrestris and screening of their antioxidant activity. Phytochemistry, 92, 153-159.

Hanschen, F. S., Herz, C., Schlotz, N., \& Kupke, F. (2015). The Brassica epithionitrile 1 cyano-2, 3-epithiopropane triggers cell death in human liver cancer cells in vitro. Molecular Nutrition \& Food Research, 59, 2178-2189. https://doi.org/10.1002/mnfr. 201500296.

Hassan, M. Al, Estrelles, E., Soriano, P., Boscaiu, M., \& Vicente, O. (2017). Unraveling salt tolerance mechanisms in halophytes: A comparative study on four Mediterranean limonium species with different geographic distribution patterns. Frontiers in Plant Science, 8(August), 1-21. https://doi.org/10.3389/fpls.2017.01438.

Ivanova, T. V., Maiorova, O. V., Orlova, Y. V., Kuznetsova, E. I., Khalilova, L. A., Myasoedov, N. A., et al. (2016). Cell ultrastructure and fatty acid composition of lipids in vegetative organs of Chenopodium album L. under salt stress conditions. Russian Journal of Plant Physiology, 63(6), 783-795. https://doi.org/10.1134/ S1021443716060054.

Jallali, I., Megdiche, W., M'Hamdi, B., Oueslati, S., Smaoui, A., Abdelly, C., et al. (2012). Changes in phenolic composition and antioxidant activities of the edible halophyte Crithmum maritimum L. with physiological stage and extraction method. Acta Physiologiae Plantarum, 34, 1-9. https://doi.org/10.1007/s11738-012-0943-9.

Jallali, I., Zaouali, Y., Missaoui, I., Smeoui, A., Abdelly, C., \& Ksouri, R. (2014). Variability of antioxidant and antibacterial effects of essential oils and acetonic extracts of two edible halophytes: Crithmum maritimum L. and Inula crithmoïdes L. Food Chemistry, 145, 1031-1038. https://doi.org/10.1016/j.foodchem.2013.09.034.

Jdey, A., Falleh, H., Ben Jannet, S., Mkadmini Hammi, K., Dauvergne, X., Ksouri, R., et al. (2017). Phytochemical investigation and antioxidant, antibacterial and anti-tyrosinase performances of six medicinal halophytes. South African Journal of Botany, 112, 508-514. https://doi.org/10.1016/j.sajb.2017.05.016.

Kafi, M., \& Rahimi, Z. (2011). Effect of salinity and silicon on root characteristics, growth, water status, proline content and ion accumulation of purslane (Portulaca oleracea L.). Soil Science \& Plant Nutrition, 57(2), 341-347. https://doi.org/10.1080/ 00380768.2011 .567398

Kang, L.-P., Wu, K.-L., Yu, H.-S., Pang, X., Liu, J., Han, L.-F., et al. (2014). Phytochemistry steroidal saponins from Tribulus terrestris. Phytochemistry, 107, 182-189.

Karakaş, S., Çullu, M. A., \& Dikilitaş, M. (2017). Comparison of two halophyte species (Salsola soda and Portulaca oleracea) for salt removal potential under different soil salinity conditions. Turkish Journal of Agriculture and Forestry, 41(3), 183-190. https://doi.org/10.3906/tar-1611-82.

Karkanis, A. C., \& Petropoulos, S. A. (2017). Physiological and growth responses of several genotypes of common purslane (Portulaca oleracea L.) under Mediterranean semi-arid conditions. Notulae Botanicae Horti Agrobotanici Cluj-Napoca, 45(2)https:// doi.org/10.15835/nbha45210903.

Kaur, T., Bhat, H. A., \& Raina, A. (2013). Glutathione regulates enzymatic antioxidant defence with differential thiol content in perennial pepperweed and helps adapting to extreme environment. Acta Physiologiae Plantarum, 35, 2501-2511. https://doi.org/ 10.1007/s11738-013-1286-x.

Kaur, T., Hussain, K., Koul, S., Vishwakarma, R., \& Vyas, D. (2013). Evaluation of nutritional and antioxidant status of Lepidium latifolium linn.: A novel phytofood from ladakh. PLoS One, 8(8), 1-9. https://doi.org/10.1371/journal.pone.0069112.

Kim, J. Y., Cho, J.-Y., Moon, J.-H., Choi, G.-C., Lee, K.-D., Ham, K.-S., et al. (2014). Change of phenylpropanoic acid and flavonol contents at different growth stage of glasswort (Salicornia herbacea L.). Food Science and Biotechnology, 23(3), 685-691.

Kim, M. J., Jun, H. Y., \& Kim, J. H. (2014). Antiadipogenic effect of Korean glasswort (Salicornia herbacea L.) water extract on 3T3-11 adipocytes. Journal of the Korean Society of Food Science and Nutrition, 43(6), 814-821.

Kim, A. Y., Kong, C.-S., Lee, J. I., Kim, H., Park, H. Y., Lee, H.-S., et al. (2012). Evaluation of novel antioxidant triterpenoid saponins from the halophyte Salicornia herbacea. Bioorganic \& Medicinal Chemistry Letters, 22(13), 4318-4322. https://doi.org/10. 1016/j.bmcl.2012.05.017.

Kim, S. M., Seo, Y. J., Oh, J., Jang, K. Y., Hwan, L. C., \& Kim, J.-S. (2017). Neuroprotective effect of halophyte Salicornia herbacea L. Is mediated by activation of heme Oxygenase-1 in mouse hippocampal HT22 cells. Journal of Medicinal Food, 20(2), $140-151$.

Klados, E., \& Tzortzakis, N. (2014). Effects of substrate and salinity in hydroponically grown Cichorium spinosum. Journal of Soil Science and Plant Nutrition, 14(1), 211-222.

Kollia, E., Markaki, P., Zoumpoulakis, P., \& Proestos, C. (2016). Antioxidant activity of Cynara scolymus L. and Cynara cardunculus L. extracts obtained by different extraction techniques. Natural Product Research, 6419(August), 1-5. https://doi.org/10.1080/ 14786419.2016 .1219864

Ksouri, R., Ksouri, W. M., Jallali, I., Debez, A., Magné, C., Hiroko, I., et al. (2012) Medicinal halophytes: Potent source of health promoting biomolecules with medical, nutraceutical and food applications. Critical Reviews in Biotechnology, 32(4), 289-326. https://doi.org/10.3109/07388551.2011.630647.

Ksouri, R, Megdiche, W., Jallali, I, Debez, A., Magné, C., Hiroko, I, et al. (2011). Medicinal halophytes: Potent source of health promoting biomolecules with medical, nutraceutical and food applications medicinal halophytes: Potent source of health promoting biomolecules with medical, nutraceutical and food applications. Critical Reviews in Biotechnology, 32(4), 289-326. https://doi.org/10.3109/07388551.2011. 630647.

Kulisic-Bilusic, T., Blažević, I., Dejanović, B., Miloš, M., \& Pifat, G. (2010). Evaluation of the antioxidant activity of essential oils from caper (Capparis spinosa) and sea fennel (Crithmum maritimum) by different methods. Journal of Food Biochemistry, 34(SUPPL. 1), 286-302. https://doi.org/10.1111/j.1745-4514.2009.00330.x.

Küpeli, E., Kartal, M., Aslan, S., \& Yesilada, E. (2006). Comparative evaluation of the antiinflammatory and antinociceptive activity of Turkish Eryngium species. Journal of Ethnopharmacology, 107, 32-37. https://doi.org/10.1016/j.jep.2006.02.005.

Lajnef, H. Ben, Ferioli, F., Pasini, F., Politowicz, J., Khaldi, A., D'Antuono, L. F., et al. (2018). Chemical composition and antioxidant activity of the volatile fraction extracted from air-dried fruits of Tunisian Eryngium maritimum L. ecotypes. Journal of the Science of Food and Agriculture, 98(2), 635-643.

Lajnef, H. Ben, Pasini, F., Politowicz, J., Tlili, N., \& Khaldi, A. (2017). Lipid characterization of Eryngium maritimum seeds grown in Tunisia. Industrial Crops and Products, 105, 47-52.

Lattanzio, V., Kroon, P. A., Linsalata, V., \& Cardinali, A. (2009). Globe artichoke: A functional food and source of nutraceutical ingredients. Journal of Functional Foods, 1(2), 131-144. https://doi.org/10.1016/j.jff.2009.01.002.

Lee, J.-N., Kim, M.-S., Kim, D. H., \& Sohn, H.-Y. (2016). Anti-oxidation and anti-thrombosis activities of different parts of Salicornia herbacea L. Korean Journal of Microbiology and Biotechnology, 44(3), 311-316.

Lisciani, R., Fattorusso, E., Surano, V., Cozzolino, S., Giannattasio, M., \& Sorrentino, L. (1984). Anti-inflammatory activity of Eryngium maritimum rhizome extracts in intact rats. Journal of Ethnopharmacology, 12, 263-270.

Loizzo, M., Calabria, U., Tundis, R., Calabria, U., \& Pisa, U. (2007). In vitro angiotensin converting enzyme inhibiting activity of Salsola oppositifolia Desf., Salsola soda L. and Salsola tragus L. Natural Product Research, 21(9), 346-351. https://doi.org/10. $1080 / 14786410701482582$.

Lone, B. A., Chishti, M. Z., Bhat, F. A., Tak, H., Bandh, S. A., \& Khan, A. (2017). Evaluation of anthelmintic antimicrobial and antioxidant activity of Chenopodium album. Tropical Animal Health and Production, 49, 1597-1605. https://doi.org/10. 1007/s11250-017-1364-y.

Lopes, A., Rodrigues, M. J., Pereira, C., Oliveira, M., Barreira, L., Varela, J., et al. (2016). Natural products from extreme marine environments: Searching for potential industrial uses within extremophile plants. Industrial Crops and Products, 94, 299-307. https://doi.org/10.1016/j.indcrop.2016.08.040.

Luczaj, L., Pieroni, A., Tardío, J., Pardo-De-Santayana, M., Sõukand, R., Svanberg, I., et al. (2012). Wild food plant use in 21st century Europe: The disappearance of old traditions and the search for new cuisines involving wild edibles. Acta Societatis Botanicorum Poloniae, 81(4), 359-370. https://doi.org/10.5586/asbp.2012.031.

Ma, Y., Guo, Z., \& Wang, X. (2017). Tribulus terrestris extracts alleviate muscle damage and promote anaerobic performance of trained male boxers and its mechanisms: Roles of androgen, IGF-1, and IGF binding protein-3. Journal of Sport and Health Science, 6(4), 474-481. https://doi.org/10.1016/j.jshs.2015.12.003.

Mahmood, T., Aslam, R., Rehman, S., \& Naqvi, S. M. S. (2013). Molecular markers assisted genetic characterization of different salt tolerant plant species. Journal of Animal and Plant Science, 23(5), 1441-1447.

Malash, B. N., Ibrahim, S. M., Ibrahim, A. S., Kabbash, A., \& El-Aasr, M. (2015). In vitro and in vivo hepatoprotective study of Inula crithmoides L., Pluchea dioscoridis ( L.) desf. And Phyllanthus reticulates poir. Journal of Pharmaceutical Sciences and Research, 7(11), 987-993

Mansour, B. R., Jilani, I. B. H., Bouaziz, M., Gargouri, B., Elloumi, N., Attia, H., et al. (2016). Phenolic contents and antioxidant activity of ethanolic extract of Capparis spinosa. Cytotechnology, 68, 135-142. https://doi.org/10.1007/s10616-014-9764-6.

Martínez Caballero, S., Carricajo Fernández, C., \& Pérez-Fernández, R. (2004). Effect of an integral suspension of Lepidium latifolium on prostate hyperplasia in rats. Fitoterapia, 75(2), 187-191. https://doi.org/10.1016/j.fitote.2003.12.016.

Mejri, H., Tir, M., Feriani, A., Ghazouani, L., Allagui, S. M., \& Saidani-Tounsi, M. (2017) Does Eryngium maritimum seeds extract protect against $\mathrm{CCl} 4$ and cisplatin induced toxicity in rats: Preliminary phytochemical screening and assessment of its in vitro and in vivo antioxidant activity and antifibrotic effect. Journal of Functional Foods, 37, 363-372.

Mekinić, I. G., Blažević, I., Mudnić, I., Burčul, F., Grga, M., Skroza, D., et al. (2016). Sea fennel (Crithmum maritimum L.): Phytochemical profile, antioxidative, cholinesterase inhibitory and vasodilatory activity. Journal of Food Science \& Technology, 53(7), 3104-3112. Revised https://doi.org/10.1007/s13197-016-2283-z.

Melliou, E., Magiatis, P., \& Skaltsounis, A. L. (2003). Alkylresorcinol derivatives and sesquiterpene lactones from Cichorium spinosum. Journal of Agricultural and Food Chemistry, 51(5), 1289-1292. https://doi.org/10.1021/jf025848g.

Meot-Duros, L., Cérantola, S., Talarmin, H., Le Meur, C., Le Floch, G., \& Magné, C. (2010). New antibacterial and cytotoxic activities of falcarindiol isolated in Crithmum maritimum L. leaf extract. Food and Chemical Toxicology, 48(2), 553-557. https://doi. org/10.1016/j.fct.2009.11.031.

Meot-Duros, L., Le Floch, G., \& Magné, C. (2008). Radical scavenging, antioxidant and antimicrobial activities of halophytic species. Journal of Ethnopharmacology, 116(2), 258-262. https://doi.org/10.1016/j.jep.2007.11.024.

Meot-Duros, L., \& Magné, C. (2009). Antioxidant activity and phenol content of Crithmum maritimum L. leaves. Plant Physiology and Biochemistry, 47(1), 37-41. https://doi. org/10.1016/j.plaphy.2008.09.006.

Michalska, K., \& Kisiel, W. (2007). Further sesquiterpene lactones and phenolics from 
Cichorium spinosum. Biochemical Systematics and Ecology, 35(10), 714-716. https:// doi.org/10.1016/j.bse.2007.03.010.

Mollica, A., Zengin, G., Locatelli, M., Stefanucci, A., Mocan, A., Macedonio, G., et al. (2017). Anti-diabetic and anti-hyperlipidemic properties of Capparis spinosa L.: In vivo and in vitro evaluation of its nutraceutical potential. Journal of Functional Foods, 35, 32-42. https://doi.org/10.1016/j.jff.2017.05.001.

Morales, P., Ferreira, I. C. F. R., Carvalho, A. M., Sánchez-Mata, M. C., Cámara, M., Fernández-Ruiz, V., et al. (2014). Mediterranean non-cultivated vegetables as dietary sources of compounds with antioxidant and biological activity. LWT - Food Science and Technology, 55(1), 389-396. https://doi.org/10.1016/j.lwt.2013.08.017.

Neves, J. M., Matos, C., Moutinho, C., Queiroz, G., \& Gomes, L. R. (2009) Ethnopharmacological notes about ancient uses of medicinal plants in Trás-os-Montes (northern of Portugal). Journal of Ethnopharmacology, 124(2), 270-283. https://doi. $\operatorname{org} / 10.1016 /$ j.jep.2009.04.041.

Ntatsi, G., Aliferis, K. A., Rouphael, Y., \& Napolitano, F. (2017). Salinity source alters mineral composition and metabolism of Cichorium spinosum. Environmental and Experimental Botany, 141(March), 113-123.

Omezzine, F., Ladhari, A., Rinez, A., \& Haouala, R. (2011). Potent herbicidal activity of Inula crithmoides L. Scientia Horticulturae, 130(4), 853-861. https://doi.org/10. 1016/j.scienta.2011.08.013.

Oueslati, S., Ksouri, R., Falleh, H., Pichette, A., Abdelly, C., \& Legault, J. (2012b). Phenolic content, antioxidant, anti-inflammatory and anticancer activities of the edible halophyte Suaeda fruticosa Forssk. Food Chemistry, 132(2), 943-947. https:// doi.org/10.1016/j.foodchem.2011.11.072.

Oueslati, S., Trabelsi, N., Boulaaba, M., Legault, J., Abdelly, C., \& Ksouri, R. (2012a). Evaluation of antioxidant activities of the edible and medicinal Suaeda species and related phenolic compounds. Industrial Crops and Products, 36(1), 513-518. https:// doi.org/10.1016/j.indcrop.2011.10.006

Ozcan, T. (2014). Fatty acid composition of seed oils in some sand dune vegetation species from Turkey. Chemistry of Natural Compounds, 50(5), 804-809. https://doi. org/10.1007/s10600-014-1088-4.

Pagnotta, M. A., Fernandez, J. A., Sonnante, G., \& Egea-Gilabert, C. (2017). Genetic diversity and accession structure in European Cynara cardunculus collections. PLoS One, 12(6), 1-23. https://doi.org/10.1371/journal.pone.0178770.

Panta, S., Flowers, T., Lane, P., Doyle, R., Haros, G., \& Shabala, S. (2014). Halophyte agriculture: Success stories. Environmental and Experimental Botany, 107, 71-83.

Pereira, C. G., Barreira, L., da Rosa Neng, N., Nogueira, J. M. F., Marques, C., Santos, T. F., et al. (2017). Searching for new sources of innovative products for the food industry within halophyte aromatic plants: In vitro antioxidant activity and phenolic and mineral contents of infusions and decoctions of Crithmum maritimum L. Food and Chemical Toxicology, 107(Part B), 581-589. https://doi.org/10.1016/j.fct.2017.04. 018.

Pereira, C. G., Barreira, L., Neng, N. da R., Nogueira, J. M. F., Marques, C., Santos, T. F., et al. (2017). Searching for new sources of innovative products for the food industry within halophyte aromatic plants: In vitro antioxidant activity and phenolic and mineral contents of infusions and decoctions of Crithmum maritimum L, 107https://doi.org/10.1016/j. fct.2017.04.018.

Petropoulos, S. A., Fernandes, A., Barros, L., \& Ferreira, I. C. (2017). A comparison of the phenolic profile and antioxidant activity of different Cichorium spinosum L. ecotypes. Journal of the Science of Food and Agriculture, 98(1), 183-189. https://doi.org/10. 1002/jsfa.8453.

Petropoulos, S. A., Fernandes, Â., Ntatsi, G., Levizou, E., Barros, L., \& Ferreira, I. C. F. R. (2016). Nutritional profile and chemical composition of Cichorium spinosum ecotypes. LWT - Food Science and Technology, 73, 95-101. https://doi.org/10.1016/j.lwt. 2016.05.046.

Petropoulos, S., Karkanis, A., Fernandes, Â., Barros, L., Ferreira, I. C. F. R., Ntatsi, G., et al. (2015). Chemical composition and yield of six genotypes of common purslane (Portulaca oleracea L.): An alternative source of Omega-3 fatty acids. Plant Foods for Human Nutrition, 70(4), 420-426. https://doi.org/10.1007/s11130-015-0511-8.

Petropoulos, S., Karkanis, A., Martins, N., \& Ferreira, I. C. F. R. (2016). Phytochemical composition and bioactive compounds of common purslane (Portulaca oleracea L.) as affected by crop management practices. Trends in Food Science \& Technology, 55, 1-10. https://doi.org/10.1016/j.tifs.2016.06.010.

Petropoulos, S. A., Levizou, E., Ntatsi, G., Fernandes, Â., Petrotos, K., Akoumianakis, K., et al. (2017). Salinity effect on nutritional value, chemical composition and bioactive compounds content of Cichorium spinosum L. Food Chemistry, 214, 129-136. https:// doi.org/10.1016/j.foodchem.2016.07.080.

Petropoulos, S. A., Pereira, C., Barros, L., \& Ferreira, I. C. F. R. (2017). Leaf parts from Greek artichoke genotypes as a good source of bioactive compounds and antioxidants. Food Function, 8(5), 2022-2029. https://doi.org/10.1039/C7FO00356K.

Petropoulos, S. A., Pereira, C., Ntatsi, G., Danalatos, N., Barros, L., \& Ferreira, I. C. F. R. (2017). Nutritional value and chemical composition of Greek artichoke genotypes. Food Chemistry. https://doi.org/10.1016/j.foodchem.2017.01.159.

Polat, R., \& Sat1l, F. (2012). An ethnobotanical survey of medicinal plants in Edremit Gulf ( Balıkesir - Turkey ). Journal of Ethnopharmacology, 139(2), 626-641. https://doi. org/10.1016/j.jep.2011.12.004.

Qasim, M., Abideen, Z., Adnan, M. Y., Gulzar, S., Gul, B., Rasheed, M., et al. (2017). Antioxidant properties, phenolic composition, bioactive compounds and nutritive value of medicinal halophytes commonly used as herbal teas. South African Journal of Botany, 110, 240-250. https://doi.org/10.1016/j.sajb.2016.10.005.

Ramadan, B. K., Schaalan, M. F., \& Tolba, A. M. (2017). Hypoglycemic and pancreatic protective effects of Portulaca oleracea extract in alloxan induced diabetic rats. BMC Complementary and Alternative Medicine, 17(37), 1-10. https://doi.org/10.1186/ s12906-016-1530-1.

Renna, M., \& Gonnella, M. (2012). The use of the sea fennel as a new spice-colorant in culinary preparations. International Journal of Gastronomy and Food Science, 1(2),
111-115. https://doi.org/10.1016/j.ijgfs.2013.06.004.

Renna, M., Gonnella, M., Caretto, S., Mita, G., \& Serio, F. (2017). sea fennel (Crithmum maritimum L.): From underutilized crop to new dried product for food use. Genetic Resources and Crop Evolution, 64(1), 205-216. https://doi.org/10.1007/s10722-0160472-2.

Ribeiro, I. C., Pinheiro, C., Ribeiro, C. M., Veloso, M. M., Simões-costa, M. C., Evaristo, I., et al. (2016). Genetic diversity and physiological performance of Portuguese wild beet ( Beta vulgaris spp. maritima) from three contrasting habitats. Frontiers in Plant Science, 7(August), 1-14. https://doi.org/10.3389/fpls.2016.01293.

Ruiz-Rodríguez, B.-M., Morales, P., Fernández-Ruiz, V., Sánchez-Mata, M., Cámara, M., Díez-marqués, C., et al. (2011). Valorization of wild strawberry-tree fruits ( Arbutus unedo L.) through nutritional assessment and natural production data. FRIN, 44(5), 1244-1253. https://doi.org/10.1016/j.foodres.2010.11.015.

Salam Jekendra, S., Joylani, S., Rebika, N., \& Priyadarshini, S. (2011). Secondary metabolites, antioxidant status and nutritive composition of two non-conventional leafy vegetables-Stellaria media $\mathrm{L}$. and Chenopodium album L. Indian Journal of Agricultural Biochemistry, 24(2), 136-140.

Šalamon, I., Grul'ová, D., \& Feo, V. De (2016). Comparison of two methods for field grow of puncture vine ( Tribulus terrestris L.) in Slovakia. Acta Agriculturae Scandinavica Section B Soil and Plant Science, 66(3), 267-271. https://doi.org/10.1080/09064710. 2015.1093652.

Sánchez-Mata, M. C., Loera, R. D. C., Morales, P., Fernández-Ruiz, V., Cámara, M., Marqués, C. D., et al. (2012). Wild vegetables of the Mediterranean area as valuable sources of bioactive compounds. Genetic Resources and Crop Evolution, 59(3), 431-443. https://doi.org/10.1007/s10722-011-9693-6.

Sangeetha, R. K., \& Baskaran, V. (2010). Carotenoid composition and retinol equivalent in plants of nutritional and medicinal importance: Efficacy of b-carotene from Chenopodium album in retinol- deficient rats. Food Chemistry, 119, 1584-1590.

Siracusa, L., Kulisic-Bilusic, T., Politeo, O., Krause, I., Dejanovic, B., \& Ruberto, G. (2011). Phenolic composition and antioxidant activity of aqueous infusions from Capparis spinosa L. and Crithmum maritimum L. Before and after submission to a two - step in vitro digestion model. Journal of Agricultural and Food Chemistry, 59, 12453-12459.

Skorupa, M., Gołebięwski, M., Domagalski, K., Kurnik, K., Nahia, K. A., Złoch, M., et al (2016). Plant Science Transcriptomic profiling of the salt stress response in excised leaves of the halophyte Beta vulgaris ssp. maritima. Plant Science, 243, 56-70.

Slama, I., Abdelly, C., Bouchereau, A., Flowers, T., \& Savouré, A. (2015). Diversity, distribution and roles of osmoprotective compounds accumulated in halophytes under abiotic stress. Annals of Botany, 115(3), 433-447. https://doi.org/10.1093/aob/ mcu239.

Sleimi, N., Guerfali, S., \& Bankaji, I. (2015). Biochemical indicators of salt stress in Plantago maritima: Implications for environmental stress assessment. Ecological Indicators, 48, 570-577. https://doi.org/10.1016/j.ecolind.2014.08.035.

Sonnentag, O., Detto, M., Runkle, B. R. K., Teh, Y. A., Silver, W. L., Kelly, M., et al. (2011) Carbon dioxide exchange of a pepperweed (Lepidium latifolium L.) infestation: How do flowering and mowing affect canopy photosynthesis and autotrophic respiration? Journal of Geophysical Research: Biogeosciences, 116(1), 1-15. https://doi.org/10. 1029/2010JG001522.

Tabassum, N., \& Ahmad, F. (2011). Role of natural herbs in the treatment of hypertension. Pharmacognosy Review, 5, 30-40.

Tardío, J., Pardo-de-Santanaya, M., \& Morales, R. (2006). Ethnobotanical review of wild edible plants in Spain. Botanical Journal of the Linnean Society, 152, 27-71.

Tlili, N., Feriani, A., Saadoui, E., Nasri, N., \& Khaldi, A. (2017). Capparis spinosa leaves extract: Source of bioantioxidants with nephroprotective and hepatoprotective effects. Biomedicine \& Pharmacotherapy, 87, 171-179.

Tlili, N., Mejri, H., Anouer, F., Saadaoui, E., Khaldi, A., \& Nasri, N. (2015). Phenolic profile and antioxidant activity of Capparis spinosa seeds harvested from different wild habitats. Industrial Crops and Products, 76, 930-935. https://doi.org/10.1016/j indcrop.2015.07.040.

Towhidi, A., Saberifar, T., \& Dirandeh, E. (2011). Nutritive value of some herbage for dromedary camels in the central arid zone of Iran. Tropical Animal Health and Production, 43(3), 617-622. https://doi.org/10.1007/s11250-010-9741-9.

Trichopoulou, A., Vasilopoulou, E., Hollman, P., Chamalides, C., Foufa, E., Kaloudis, T., et al. (2000). Nutritional composition and flavonoid content of edible wild greens and green pies: A potential rich source of antioxidant nutrients in the Mediterranean diet. Food Chemistry, 70(3), 319-323. https://doi.org/10.1016/S0308-8146(00)00091-1.

Tuan, N. Q., Lee, W., Oh, J., Kwak, S., Lee, H. G., Ferreira, D., et al. (2015). Quinic acid derivatives from Salicornia herbacea alleviate HMGB1-mediated endothelial. Journal of Functional Foods, 15, 326-338. https://doi.org/10.1016/j.jff.2015.03.044.

Tundis, R., Loizzo, M., Statti, G., \& Menichini, F. (2007). Inhibitory effects on the digestive enzyme alpha-amylase of three Salsola species (Chenopodiaceae) in vitro. Die Pharmazie, 62(6), 473-475.

Tundis, R., Menichini, F., Conforti, F., Loizzo, M. R., Statti, G., Menichini, F., et al. (2009) A potential role of alkaloid extracts from Salsola species (Chenopodiaceae) in the treatment of Alzheimer's disease. Journal of Enzyme Inhibition and Medicinal Chemistry, 24(3), 818-824. https://doi.org/10.1080/14756360802399662.

Turgut, N. H., Kara, H., Arslanbas, E., Mert, D. G., Tepe, B., \& Gungor, H. (2015). Effect of Capparis spinosa L. on cognitive impairment induced by D-galactose in mice via inhibition of oxidative stress. Turkish Journal of Medical Sciences, 45(5), 1127-1136. https://doi.org/10.3906/sag-1405-95.

Turner, N. J., Łuczaj, Ł. J., Migliorini, P., Pieroni, A., Dreon, A. L., Sacchetti, L. E., et al. (2011). Edible and tended wild plants, traditional ecological knowledge and agroecology. Critical Reviews in Plant Sciences, 30(December), 198-225. https://doi.org/10. 1080/07352689.2011.554492.

Uddin, M. K., Juraimi, A. S., Hossain, M. S., Nahar, M. A. U., Ali, M. E., \& Rahman, M. M. (2014). Purslane weed (Portulaca oleracea): A prospective plant source of nutrition, omega-3 fatty acid, and antioxidant attributes. The Scientific World Journal6. https:// 
doi.org/10.1155/2014/951019.

Vale, F., Zanolla Dias de Souza, K., Rezende, C., \& Geber, S. (2017). Efficacy of Tribulus terrestris for the treatment of premenopausal women with hypoactive sexual desire disorder: A randomized double-blinded, placebo-controlled trial. Gynecological Endocrinology. http://dx.doi.org/10.1080/09513590.2017.1409711 Retrieved from.

Wang, X., Zhang, M., Zhao, Y., Wang, H., Liu, T., \& Xin, Z. (2013). Pentadecyl ferulate, a potent antioxidant and antiproliferative agent from the halophyte Salicornia herbacea. Food Chemistry, 141(3), 2066-2074. https://doi.org/10.1016/j.foodchem. 2013.05.043.

Wang, J., Zu, X., \& Jiang, Y. (2009). Five furostanol saponins from fruits of Tribulus terrestris and their cytotoxic activities. Natural Product Research, 23(15), 1436-1444.

Weber, D. J., Ansari, R., Gul, B., \& Ajmal Khan, M. (2007). Potential of halophytes as source of edible oil. Journal of Arid Environments, 68(2), 315-321. https://doi.org/10. 1016/j.jaridenv.2006.05.010.

Wei, S., Fukuhara, H., Chen, G., Kawada, C., Kurabayashi, A., Furihata, M., et al. (2014). Terrestrosin D, a steroidal saponin from Tribulus terrestris L. Inhibits growth and angiogenesis of human prostate cancer in vitro and in vivo. Pathobiologie, 81(3), 123-132.

Xiang, Y., Haixia, W., Lijuan, M., \& Yanduo, T. (2017). Isolation, purification and identification of antioxidants from Lepidium latifolium extracts. Medicinal Chemistry
Reseacrh. https://doi.org/10.1007/s00044-017-2042-3.

YouGuo, C., ZongJi, S., \& XiaoPing, C. (2009). Evaluation of free radicals scavenging and immunity-modulatory activities of Purslane polysaccharides. International Journal of Biological Macromolecules, 45(5), 448-452. https://doi.org/10.1016/j.ijbiomac.2009. 07.009 .

Yurdakök, B., \& Baydan, E. (2013). Cytotoxic effects of Eryngium kotschyi and Eryngium maritimum on Hep2, HepG2, Vero and U138 MG cell lines. Pharmaceutical Biology, 51(12), 1579-1585. https://doi.org/10.3109/13880209.2013.803208.

Zardi-Bergaoui, A., Nejma, A. Ben, Harzallah-Skhiri, F., Flamini, G., Ascrizzi, R., \& Janet, H. Ben (2017). Chemical composition and biological studies of the essential oil from aerial parts of Beta vulgaris subsp. Maritima ( L.) a RCANG. Growing in Tunisia. Chemistry and Biodiversity, 14(e1700234), 1-8. https://doi.org/10.1002/cbdv. 201700234.

Zhao, Y., Wang, X., Wang, H., Liu, T., \& Xin, Z. (2014). Two new noroleanane-type triterpene saponins from the methanol extract of Salicornia herbacea. Food Chemistry, 151, 101-109. https://doi.org/10.1016/j.foodchem.2013.11.030.

Zurayk, R. A., \& Baalbaki, R. (1996). Inula crithmoides: A candidate plant for saline agriculture. Arid Soil and Rehabilitation, 10, 213-223. https://doi.org/10.1080/ 15324989609381436. 